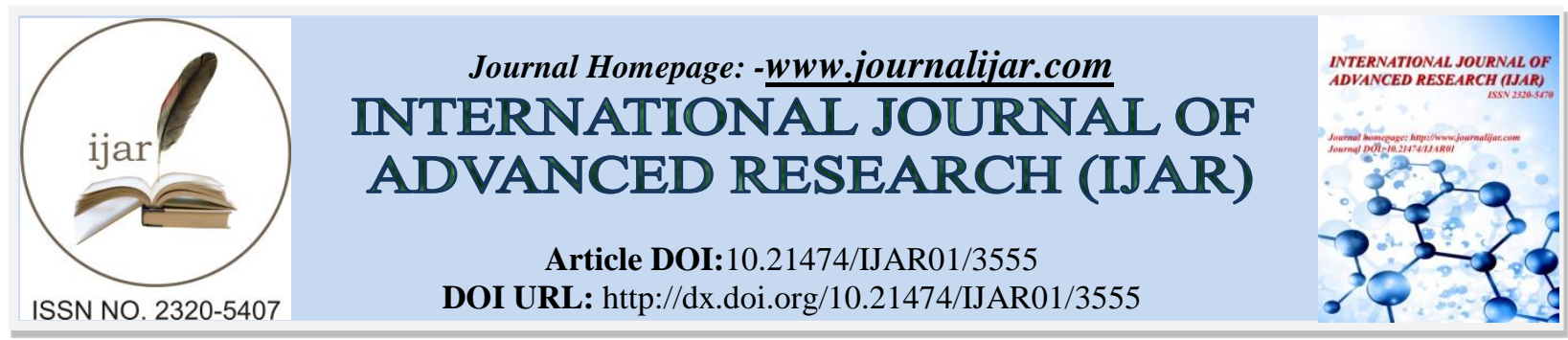

RESEARCH ARTICLE

\title{
THE APOCALYPTIC ANTHROPOCENE EPOCH AND ITS MANAGEMENT IN INDIA
}

\author{
Dr. Siba Prasad Mishra.
}

Civil Engineering Department, Centurion University of Technology and management, Jatni, Khordha

\section{Manuscript Info}

Manuscript History

Received: 02 January 2017

Final Accepted: 04 February 2017

Published: March 2017

Key words:-

Anthropocene, Holocene, epoch, GHG gasses, global warming, asteroids, MSL rise, Earthquake

\begin{abstract}
The very existence of Holocene is debated for its tenure and transcendence by anew epoch "The Anthropocene or the age of man". The transition between two epochs is in breakthrough dialogue as human intervention to enact the hydro-meteorological, geological and biological stratigraphic changes. The homo-sapiens are the dominant forces where the earth is exponentially transforming. The exo-planet aliens, PHAs or NEOs can drive the new epoch to be apocalyptic. The era is considered as Eurocentric and launched either from Industrial revolution or from dates of nuclear explosion. The human centric activities like modernization, advancement in science, technology, hydrologic interventions, disproportionate GHG's etc. are the indicators of the new eon. The researchers have wide scope now to use ample anthropogenic, climatic, biologic and geologic data for study but which was underreported or non-reported in past. The burgeoning data available from NASA, FAO, disaster sectors, geo-engineering and bioengineering etc. have been used for the present study. The legacy of the Anthropocene is said to have propagated in spells and phases from Europe to Indian subcontinent. The shift of the epoch is geospatial in geographical time scale. The present study envisages a nonparametric approach about the influence of the earth system of Indian subcontinent by human impact. Investigation is done to ascertain the causes, impacts, effects, longevity of the human dominance over natural variability. The Anthropocene is greatly accelerated with the great oxidation and carbonization processes but the effect of the epoch can be delayed and decelerated by development in geo engineering, bio engineering, smart technology and Nano science etc. The spell, its identity, uniqueness and management of the epoch to avoid both ecologic and economic extinction are discussed in the present research.
\end{abstract}

Copy Right, IJAR, 2017, All rights reserved.

\section{Introduction:-}

Hominids predominate in the Holocene epoch as per the records of International Commission on Stratigraphy (ICS). But the concept of succession of the new epoch, "The Anthropocene", was claimed by a Dutch chemist Paul Crutzen, Stoermeron in (2000) ${ }^{[1]}$, Crutzen (2002) ${ }^{[2]}$. The working groups of International Union of Geological Sciences (IUGS) though not officially, declared the onset of the epoch Anthropocene, but admitted about the planetary shift of the new geological age. The epoch relates to the word "anthropo" (man) and "cene" (new) where the Homosapiens have dominated the atmosphere, earth crust, ocean, and nutrient cycles. 
Geologically Mesozoic era (the age of dinosaurs), then Cenozoic era (the period of mammals) were succeeded by the Quaternary period without human activities till the tertiary era Fig 1(a). The Quaternary period consisted of the Pleistocene when Homosapiens developed their activities (2588000 to 11700 years BP) succeeded by the Holocene (11700 years BP to present). Present period is the Pleistocene interglacial age accepted by the International Geological Congress in Bologna in 1885, Steffen et. al., (2007) ${ }^{[3]}$. The Holocene age is classified as early, (117008000BP), mid (7999- 4500BP) and late (4500 BP to till date). It prevailed from the warmest period (hunter stone age) after a long ice age during upper Pleistocene period (http://www.stratigraphy.org/ICSchart). Thereafter drop in temperature was observed during the little ice age which continued till $1700 \mathrm{AD}$ in northern Hemisphere. The temperature further started rising from 1700 to 2000AD but not like hunter stone age. The Holocene had many small ice ages and warm periods like Minoan, Roman and Medieval with only one prominent cold period i.e. "The little ice age" (http://www.dandebat.dk/eng-klima7.htm)Fig 1 (a), Fig 1 (b).

Now the researchers have wide scope for anthropogenic, climatic and geologic studies with ample data which went underreported and non-reported evenupto $19^{\text {th }}$ century. Present study reveals the causes, period of prevalence and felicitation of the impact and future effects of the new epoch. The period of start of the epoch, impact of the predictors, parameters, indicators, age and management in Indian subcontinent are discussed in the present research.

Quaternary Period with the Anthropocene Epoch (AWG of ICS, 2016)

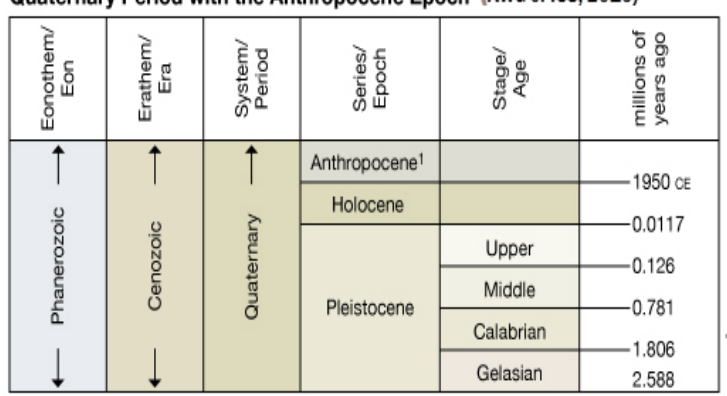

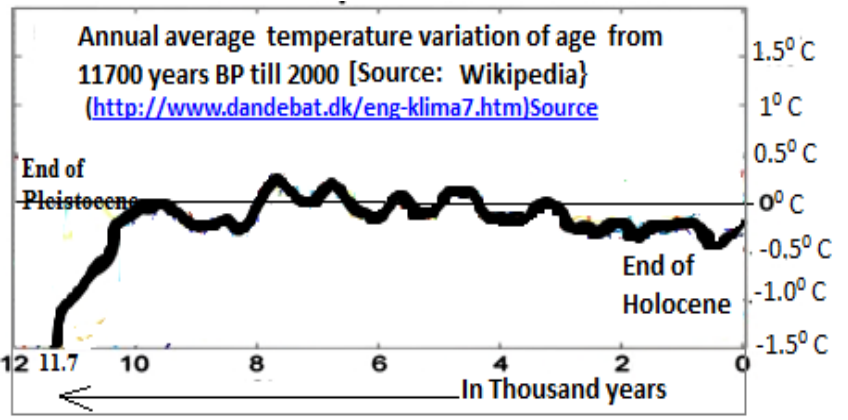

Fig 1(a):- The geological age where the Anthropocene succeeds the Holocene Fig 1(b): The temperature anomaly which shows an average temp change of $0-2^{0} \mathrm{C}$ brings a drastic transformation in the globe.

\section{Review of literature:-}

The Anthropocene entered the geological literature by Paul Cruzen (2002) ${ }^{[2]}$ and further acknowledged by different scientists and engineers like Steffen et al., (2004) ${ }^{[4]}$, Syvitski et al., (2005) ${ }^{[5]}$, Crossland, (2005) ${ }^{[6]}$, Anderson et al., (2005) ${ }^{[7]}$ informing about the end of the Holocene epoch and start of a new epoch where the environment is overruled by human commotion. Anthropogenic activities are the deciding factors in the change of climate, reported by the working group of the Intergovernmental Panel on Climate Change (IPCC). In their assessment report AR3 $(2001)^{[8]}$, AR4 (2007) ${ }^{[9]},(2010)^{[10]}$ and AR5 (2014) ${ }^{[11]}$ have reported the human activities vs. climatic and hydrologic changes (dominant being global warming) are interrelated by $66 \%$ (certainly), $90 \%$ (very likely) and 95\% (extremely likely) from 1950's respectively. Sir David Attenborough, (2006) ${ }^{[12]}$ claimed record-breaking cold waves and rainfall in some parts of the globe disapproves the global warming and made a distinction between the climatic change and weather patterns. WMO have reported 1990's is the warmest century of the millennium.

Stormberg, (2013) ${ }^{[13]}$ has reported that two billion years ago, vast proliferation of the oxygenated cyanobacteria in the atmosphere, forcefully made the living creatures on the earth to an extinct species. Presence of late quaternary strata with youngest Toba Tephra events (Toba super volcanic eruption) in the basins of peninsular rivers, carried valley sediments due to wetted monsoonal phase in the deltas. Hominid fossils (short and stocky pygmies) became extinct in central India during that period. Tandon et. al (2014), ${ }^{[14]}$ Peter Fisher, (2014) ${ }^{[15]}$ rightly stated that progenitors shall have a horrid mechanical future and current species are under mass extinction and we will generate a polluted world by inventing novice chemicals .Bruice hall, $(2015)^{16]}$ have reported that the Anthropocene epoch shall devastate India as $70 \%$ of houses shall be constructed due to migration from rural to urban areas. The wells, rivers and farms shall run dry and be abandoned. India shall produce $4 \%$ of GHG gasses of the globe and $40 \%$ of population shall have inadequate energy. According to Matt Atherton, 2016 $6^{[17]}$, identified five causes for the Anthropocene epoch are Industrialization, population, new materials, Biogenic changes and changing water ways. The Anthropocene epoch started with industrial revolution in early $16^{\text {th }}$ century or as consequences of testing of the first atom bomb in 1940's or from the date of start of nuclear weapons in 1960's. Osborne claims the epoch was 
initiated with geologic activities like meteorite slamming, volcanic eruptions, continents shifting, earth quake and the atomic explosions Hannah Osborne, $(2015)^{[18]}$.The start of his epoch has been a subject of much debate. Some have said it started during the Industrial Revolution from 1760, while others have suggested nuclear weapons testing in the 1960s heralded in a new era in the planet's history "the Anthropocene" Stanley et al $(2016)^{[19]}$.Steffen, $(2007)^{3}$ reported that "The great acceleration" of human forcing on the planet have started a new age 1950's onwards. Davos, (2017) [61], deliberated 12 parameters of anthropogenic forcing and 12 parameters of environment activity of the Earth's systems responsible for the change in the geographic period "the Anthropocene".

\section{The Anthropocene epoch in controversy:-}

To establish the new epoch, selection of a Global Boundary Strato type Section and Point (GSSP) or acceptance of its inception date need be approved by the ICS (International Commission on Stratigraphy) to find a place in GSSA (Global Standard Stratigraphic Age). We are in the Phanerozoic Eon, Cenozoic era, Quaternary period and Holocene epoch as per ICS calendar till date. The IUGS, an official unit of the ICS, is yet to approve the epoch "the Anthropocene" Zalasiewicz et al $(2008){ }^{[20]}$, 2010 $\left.{ }^{[21]}\right)$.The ICS Sub-commission on Quaternary Stratigraphy established a working group in 2009 to address the strategy. Since then, discussion and deliberations on of the Anthropocene became extensive in scientific publications, the public media and in the greater academic sphere. The proposal that the confusion between the definition Chrono-stratigraphic unit as system, series, stage and Geochronologic units as period, epoch, age adopted by GSSPs, as unit, the Anthropocene was rejected in ICS workshop (2010), Zalasiewicz et al. (2014) ${ }^{[22]}$.To have a breakthrough to the dialog on the epoch, Anthropocene, congregation of the group is going to meet at Cavallo Point, Sausalito, California from 21st June to 23rd June, 2017.

\section{Anthropocene, Indian scenario:-}

The Anthropocene is unofficially accepted with (a) priming period from the age of last warm period from 3000 years BP to $18^{\text {th }}$ century (b) the margin (1850-1944) (C) the fundamental shifts(1945- 1980), (d) The great acceleration (1981 to till date). The geospatial behavior of the epoch had impacts in phases which changed the human activities from hunting and farming to the modern life. Presently it is to be accepted that we are in the Anthropocene epoch in India. The admittance of the new epoch has become more factual than less political today as reported by Zalasiewicz et al (2014) ${ }^{[23 \mathrm{a} \& \mathrm{~b}]}$..

\section{Establishing the shift in India:-}

The Priming (3000BP-1849AD):

Early human impacts on the land use and land cover started from the great warm period, 3000 years BP (Barnosky, $2008^{[24]}$, Ellis et al 2011, 2012, 2013, 2014[ ${ }^{25-28]}$ and Wilkinson et al 2014) ${ }^{[29]}$.Many terrestrial biotic and marine micro biotic changes altered the $\mathrm{CO}_{2}$ levels due to socio political developments, conversion from hunting to agriculture. continuous formations in the Himalayan range of mountains, undermining of the river Saraswati, desertification of Thar in India, decline of the ancient civilizations, the Mohenjo-Daro and the Harappa are the artifacts of formation of the new epoch. The pollen grain tests, carbon dating data and strand line records indicate about the reforms of land scape. The conversion of gulfs to lagoons/lakes (the Chilika Lagoon and the Pulikat Lake), marks of high MSL (mean sea level) along coast, conversion of jungles to rural settlements with the knowledge of making metals and alloys indicate about the end of the Holocene era. Archeological findings of underwater monuments at Mahabalipuram, Vet-Dawrika, Ram Setu at Rameswarm etc. relate to the eon changes in Indian subcontinent during the Paleo-Anthropocene period Foley et al. (2013) ${ }^{[30]}$.

\section{The Margin (1850-1944):-}

Sixteenth century is considered to have exhibited noteworthy changes in the world due to continental drive and collision of the meteorological asteroid (The golden Spikes) with major climate changes quoted from Mark Muslim by Rebecca Morelle, $(2015)^{[31]}$.The stratigraphic Eurocentric boundary of early Anthropocene reported by Crutzen and Stoermer $(2000)^{[1]}$, Crutzen $(2002)^{[2]}$, Water's et al., $(2014)^{[32]}$ clearly link to the industrial revolution of $19^{\text {th }}$ century with use of the coal based steam engines, shipping and boilers along with the population explosion. The anthropogenic activities shifted gradually to North America, China, India, Japan and many other countries throughout the globe. Industrialization and urbanization are the stratigraphic signals. Energy balance, $\mathrm{CO}_{2}$ level and devastating famines in India during $19^{\text {th }}$ century are the global indicators to recognize this early Anthropocene. The Q-class NEA asteroids named Apollo 1862, having dimension $1.7 \mathrm{~km}$ were the potentially hazardous asteroid (PHA) which along with erratic El Nino southern oscillation activities (ENSO) might have caused meteorological famines in India in the $19^{\text {th }}$ century. The gigantic meteor that slammed Tunguska region of Siberia in 1908 has left the debris and carbon particles scattered in the atmosphere with very high energy which had the impact of huge mass 
extinction of species. Erratic rainfall, massive recurrent floods with heavy sediment inflow and huge death due to vectors indicate the drive of the new age in India.

\section{The fundamental shift-Anthropocene (1945-1980):-}

The demography, the energy balance, GDP vs. ecological changes, amount of carbon, drastic climatic changes and globalization brought an end to the influence of the Holocene era by mid- $20^{\text {th }}$ century (Steffen et. al $2004^{[33]}, 2007^{[3]}$, Barnosky, 2008 ${ }^{[24]}$ and $2014^{[35]}$, Steffen et al. $2007^{[312}$. The human impacts which motivated the era from 1945after the testing of Trinity A-bomb at Alamogordo, New Mexico, 1945 and Hiroshima and Nagasaki in World War II, 1945 brought the fundamental shift. More than 500atomic tests were conducted then which increased the nuclides in the atmosphere due to the fission and fusion activities. The circulation of the nuclear debris $(14 \mathrm{C}, \mathrm{Pu}-239, \mathrm{Pu}-240$, Cs-137) received from radio activities drastically changed the atmospheric extension and metabolism, Walker, $(2005)^{[36]}$.Drilling activities in mines, petroleum wells, oil spills from marine oil tankers, hydrologic interventions, diesel and petrol engines, infrastructural developments, industrial/ agricultural-related signals, uses of plastic, techno fossils are considered trig goring as the transit for the early Anthropocene in the globe and also in Indian sub-continent, Zalasiewicz et. al., (2014) ${ }^{[23]}$, Hancock et al., $(2014)^{[37]}$, Wolff, $\left(2014^{[38]}\right.$ ); Waters et al., $(2015)^{[39]}$, Morrison $\left(2015^{[40]}\right)$, Jain et al $(2016)^{[41]}$.

\section{The great acceleration:-}

The Anthropocene epoch was focused on a small population consisting of the Organization for Economic Cooperation and Development (OECD) countries during the fundamental shift period only. The prolongation of the changes became rapid, homogeneous, consistent and widespread all over the world with the great acceleration trend from 1980 onwards - till date. With reduction of the British territory there was the fast growth of tourism, circuit engineering, science, technology, industry, urban development and economic ties all over the world. The human impact on the biosphere accelerated in the developing countries like India, China, Brazil and Indonesia and many other countries. Terrestrial mini asteroid, Chelyabinsk fire ball, 2012 DA14, ,orbiting at a distance of $2700 \mathrm{~km}$ blocked the solar radiation covered significantly resulting in meteorological catastrophe like chilled Japan during winter Dec. 2012 to Feb. 2013 (NASA). Emphasis on technology, geo-engineering, green engineering, Nano science, genome and dechronification technology and many others have changed the human decree over nature.

\section{Substantiating the Anthropocene:-}

Davos, (2014), stated 12 parameters of anthropogenic forcing are global warming, greenhouse gas (GHGs) emissions, polymerization, oceanic acidification, eutrophication, industrialization, urbanization and deforestation etc. The signatures related to Anthropocene are habitat loss, species invasions, mass extinction, predation, damming, GDP changes, and energy consumption and many physical and chemical changes, etc... He also pointed other 12 non-anthropogenic parameters of the Earth's systems which can cause devastation and shift of epoch are the Sun earth geometry, ozone depletion, volcanic eruption, tsunamis, earth quakes, oceanic disturbances, coastal erosion, PHAs, NEAs and biodiversity changes etc.

The Anthropocene epoch can be substantiated mainly in India by massive extinction of species ecologically, the global warming, rise in concentration of $\mathrm{CO}_{2}$. Global warming has accelerated melting of ice and retreating of glaciers which have changed the ecology and biodiversity of the Himalayan glaciers.

Plastics and building wastes and its layers started forming as stratigraphic layers in soil for the future. A stable layer of airborne particulates of sediment and glacial ice shall accrue black carbon from $\mathrm{CO}_{2}$. There shall have large impact on the nitrogen, phosphorous cycle due to excessive use of NPK fertilizers. Creation of dead zone in sea due to eutrophication shall occur for the aquatic biome. Conversion of forests to settlements, cropland, grazing zone and livelihood are the signals for the Anthropocene in India Fig 2 (a), Fig 2 (b) and Fig 2(c). 

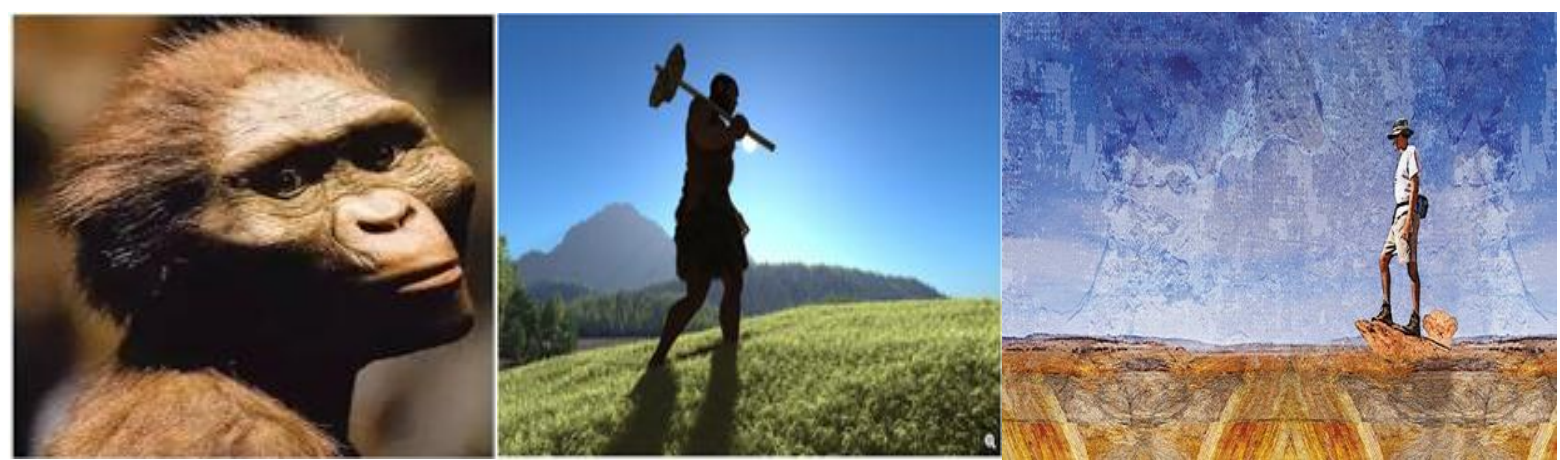

Fig 2(a):-Man pre Holocene epoch (Indian express $2^{\text {nd }}$ Mar 2017), Fig 2(b) Man in Holocene epoch (http://www. livescience. com/28219-holocene-epoch.html) Fig 2 (c): Man in Anthropocenehttp:

//www.smithsonianmag.com/science-nature/what-is-the-anthropocene-and-are-we-in-it-

164801414/http://www.livescience.com/28219-holocene-epoch.html

\section{Areall monstrous disasters anthropogenic?}

Table-1 depicts ten major disasters in India and in the globe. Except one, none of the disasters of the world was anthropogenic. They were either hydro-meteorological or geological which negates the fact that the new epoch is human centric. But it has been established that by proper management and adaptation, the impacts from hydrometeoric or geologic disaster can be ameliorated and fatalities can be reduced Examples are the great Bihar famine 1966-67, the drought in Maharashtra 1970-73 and the VSCS Phailine- 2013 where the demographic consequences were less.

Table 1:- The monstrous disasters in the globe and in India from past records available

\begin{tabular}{|c|c|c|c|c|c|c|c|}
\hline & \multicolumn{3}{|l|}{ INDIA } & \multicolumn{4}{|c|}{ WORLD } \\
\hline year & Name and place & $\begin{array}{l}\text { Death } \\
\text { Million }\end{array}$ & $\begin{array}{l}\text { Proponent } \\
\text { (changes) }\end{array}$ & year & Name and place & $\begin{array}{l}\text { Death } \\
\text { Million }\end{array}$ & Proponent \\
\hline 1770, & $\begin{array}{l}\text { The Bengal Famine } \\
\text { (Bihar/Odisha/ WB) }\end{array}$ & 10.0 & Climate & 1887 & $\begin{array}{l}\text { Yellow river flood, } \\
\text { China }\end{array}$ & $0.9-2.0$ & climatic \\
\hline 1737 & $\begin{array}{l}\text { Calcutta } \quad \text { Cyclone } \\
\text { (Bangladesh/WB) }\end{array}$ & 0.35 & Climate & 1920 & $\begin{array}{l}\text { Haiyuan earthquake, } \\
\text { China }\end{array}$ & 0.273 & Geologic \\
\hline 1839 & Coringa Cyclone (AP) & 0.32 & Climate & 1931 & China flood & $1-4$ & climatic \\
\hline 1876 & The Great Famine (India) & 30 & Climate & 1975 & $\begin{array}{ll}\text { Typhoon } & \text { Nina } \\
\text { (Banqiao } & \text { Dam } \\
\text { failed) } & \\
\end{array}$ & 0.23 & anthropogenic \\
\hline 1993 & $\begin{array}{l}\text { Latur Earthquake } \\
\text { (Latur and Osmanabad) }\end{array}$ & 0.02 & Geologic & 1970 & $\begin{array}{l}\text { Bhola Cyclone, } \\
\text { India/Bangladesh }\end{array}$ & $\begin{array}{l}0.25- \\
0.50\end{array}$ & climatic \\
\hline 1999 & Odisha Super Cyclone & 0.01 & Climate & 1976 & $\begin{array}{ll}\text { Shaanxi tremor, } \\
\text { China }\end{array}$ & 0.83 & Geologic \\
\hline 1876 & $\begin{array}{ll}\text { Great } & \text { Backerganj } \\
\text { Cyclone } & \\
\end{array}$ & 0.2 & Climate & 2010 & Haiti earthquake & 0.16 & Geologic \\
\hline 2001 & $\begin{array}{l}\text { Gujarat Earthquake } \\
\text { (Rajasthan and Gujarat }\end{array}$ & 0.02 & Geologic & 2004 & $\begin{array}{l}\text { Indian Ocean up- } \\
\text { heaval\&tsunami }\end{array}$ & 2.8 & Geologic \\
\hline 2004 & $\begin{array}{l}\text { Indian Ocean Tsunami, } \\
\text { South Andaman Nicobar }\end{array}$ & 0.2 & Geologic & 1920 & Haiyuan earthquake & 2.73 & Geologic \\
\hline 2013 & $\begin{array}{ll}\text { Uttarakhand } & \text { Flash } \\
\text { Floods, India/ } & \text { West } \\
\text { Nepal } & \end{array}$ & 0.05 & Climate & & Tangshan earthquake & $\begin{array}{l}2.42- \\
6.55\end{array}$ & Geologic \\
\hline
\end{tabular}

\section{Footprints of Anthropocene in India:-}

\section{Burgeoning Demography:-}

The analysis of population growth rate in the world and India have shown continuous rise from 1960-70 onwards, the annual population growth is declining from 1960-70 onwards till date. The population growth of poultry have 
risen abruptly with the demographic growth of people where as growth of other live stocks is slow as against human growth. The impact of demography in the earth, India and population variations of the live stocks are in Fig 3 (a)
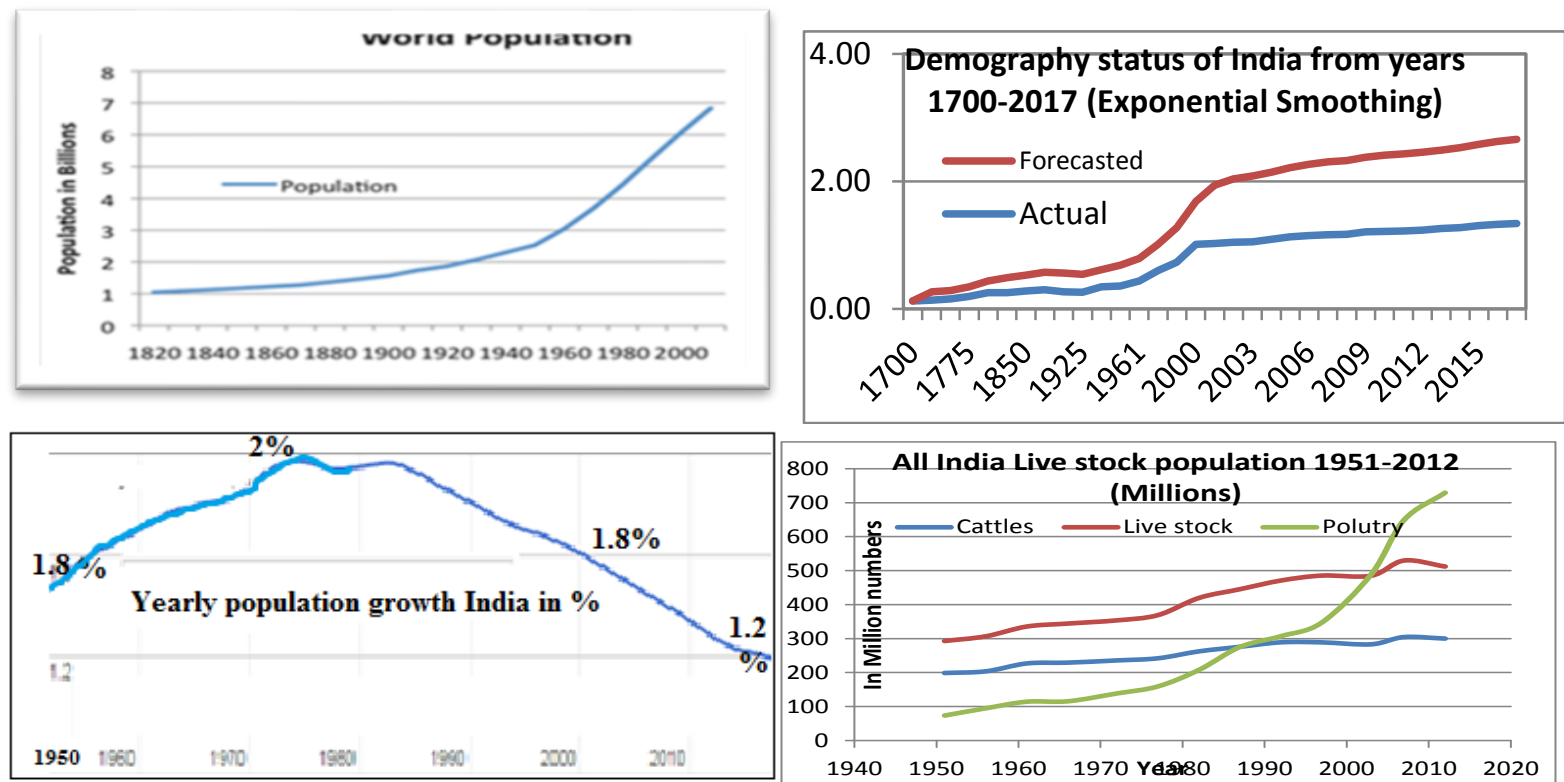

Fig 3(a):- The world, Fig 3 (b)Indian population and Fig 3 (d) livestock population, India from the year 1950 -2017

Fig 3 (c) the rate of population growth from 1980 onwards (source:http://www .populstat. info/Asia/indiac.htm Source:https://ourfiniteworld.com/2012/03/12/

\section{Hydro-meteorological extremes:-}

The Climatologic indicators for the Anthropocene are GHG's, water, Waste, Biomass, LU\&LC, vectors, microorganisms, transport and energy whereas the observed events are Cold wave, fog, snow storms and avalanches, hailstorm, thunderstorm, smog, dust storms, heat waves, avalanche, lightening, heavy rain, floods, saline water intrusion, droughts and many others. The global climatic observing system (GCOS) and their essential climatic variables (ECVs) are the watchers recording about 50 atmospheric parameters (Surface, upper air and compositions of GHG's, ozone layer, aerosols and reinforced by their antecedents), Oceanic (Surface and subsurface and terrestrial). The sectors where impacts observed are ocean, rainfall, temperature, biodiversity, health, soil, agriculture, disasters and extreme events.

\section{Rainfall/snow fall:-}

Monsoon rainfall in India from post Holocene and pre Anthropocene, from year 800 to 2200 AD (modeled) Fig 4 (b) shows the rise and fall. After 2020 during Indian South west monsoon shall decrease Fig 4(a). There shall be increase in rainy days and decrease in frequency of depression and SW monsoon annual rainfall particularly in Himalaya region Fig 4(a). The peak rainfall shall decrease in NE India which was giving maximum rainfall in India (Cherapunji). Rainfall in peninsular India shall decrease. Summer Monsoon in India may have abrupt transitions and fail due to climate change Jacob et al, $\left(2012^{[42]}\right)$, Leverman A $(2009)^{[43]}$. The western disturbances originating from Caspian Sea have increased in frequency, intensity and duration during the epoch.
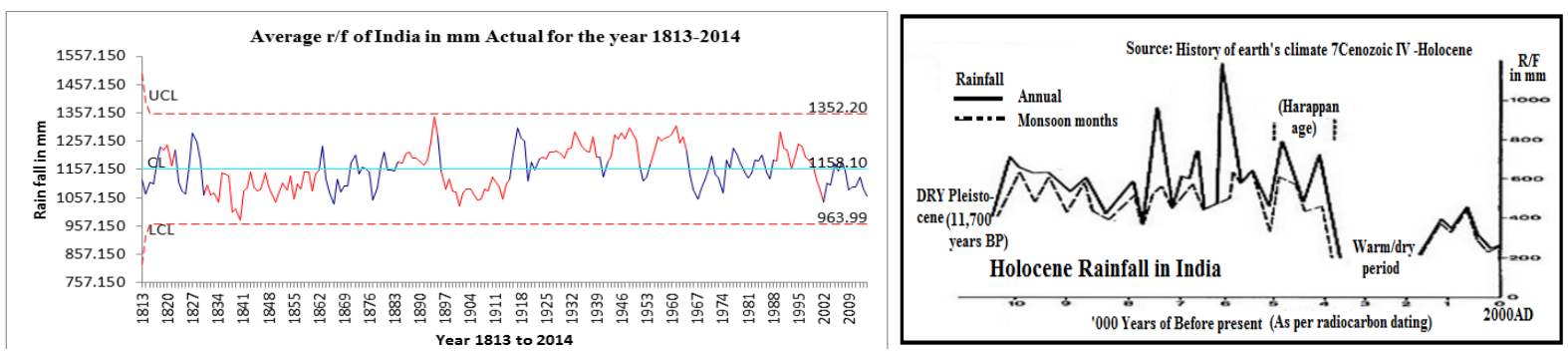

Fig 4(a):- Monsoon rainfall in India (year 1813 to 2009 AD) Fig 4 (b): The monsoon and annual rainfall of western India in Holocene period (radio carbon dating). (source: H. H. Lamb, Climate, History and the modern world) 


\section{The storms, floods and droughts:-}

The storms, earth quakes, tsunamis and famines are the monstrous killers in the Indian subcontinent during Anthropocene. $30 \%$ and, $25 \%$ of cyclonic storms formed in of Bay of Bengal and Arabian Sea respectively have risk for 32crores of coastal people. The new epoch has invited urban floods which engulfed the cities like Calcutta, Bombay, Chennai and Bhubaneswar in great acceleration period in India due to impervious concrete jungles and inadequate drainage system. Poor people are sustainable to high impact due to increased floods and droughts. WG I, IPCC, AR- $5^{[11]}$ reported that India shall face mortality of $86 \%$ from tropical storms. The SLR and storm impact can enhance significant vulnerability with climate changes. Droughts and famines are the signals of the end of Holocene in $19^{\text {th }}$ and $20^{\text {th }}$ century (fig 5 (a), 5(b) and 5(c)).

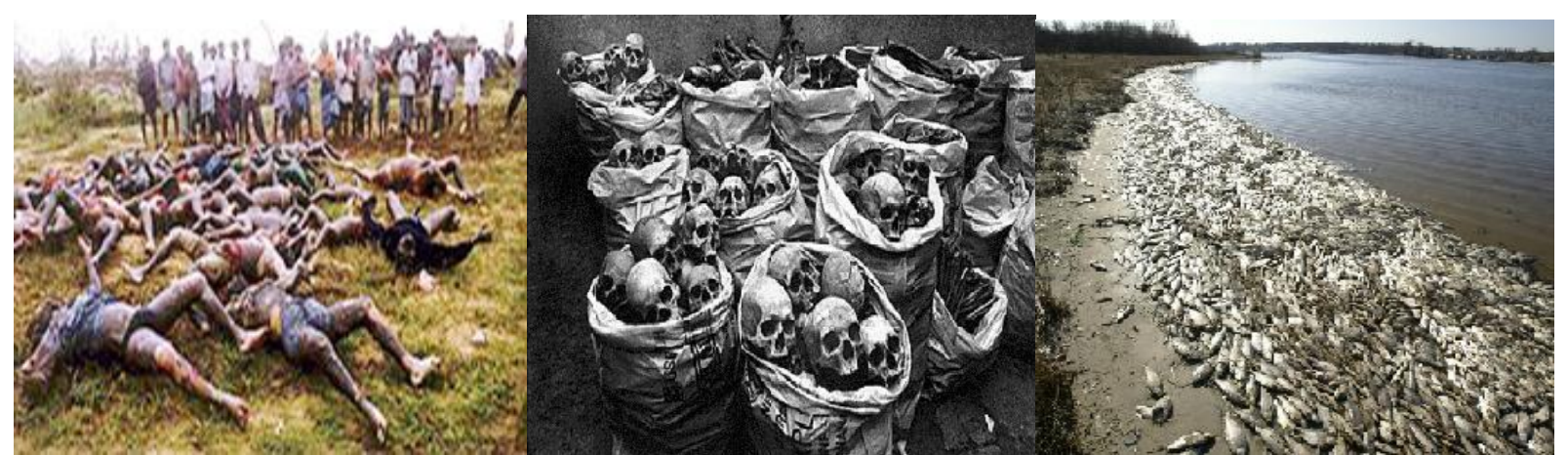

Fig 5(a):- Sup. Cyclone Odisha 1999 (b) Bhopal gas woes (1972) by S.N. Sardi (c) Extinct fishes-2016 M. Snyder

\section{Global warming:-}

World Bank Group pointed about prevalence of historical warm climate from 1970-80and predicted that $4^{\circ} \mathrm{C}$ rise shall have substantial impact on agricultural yield in India. Deccan plateau shall form zones of "Heat Islands" triggering frequent floods and drought. Wet year shall be wetter and dry years shall be drier. IPCC (AR-5) estimated small average change in SAT and SST of the earth during 1906 to 2005 the change was $0.74^{\circ} \mathrm{C}$. About $90-95 \%$ of global warming is transferred to sea. The National Oceanic and Atmospheric Administration (NOAA) have fixed seven increasing indicators (SST, SAT, Ocean air temperature, MSL, oceanic heat content and inland temperature) and three decreasing indicators (glaciers, snow cover and icebergs in sea).The critical high temperature shall shift to Oct in northern region and in south India, to pre-monsoon (April and June). The early paddy shall have bumper yield in south India, and devastate coral reefs by bleaching action Koronowski, $(2016)^{[44]}$. It is observed that the rise of $5^{0} \mathrm{C}$ in SST shall cause SAT rise of $2^{0} \mathrm{C}$ inland Fig 6 (a) and (b).

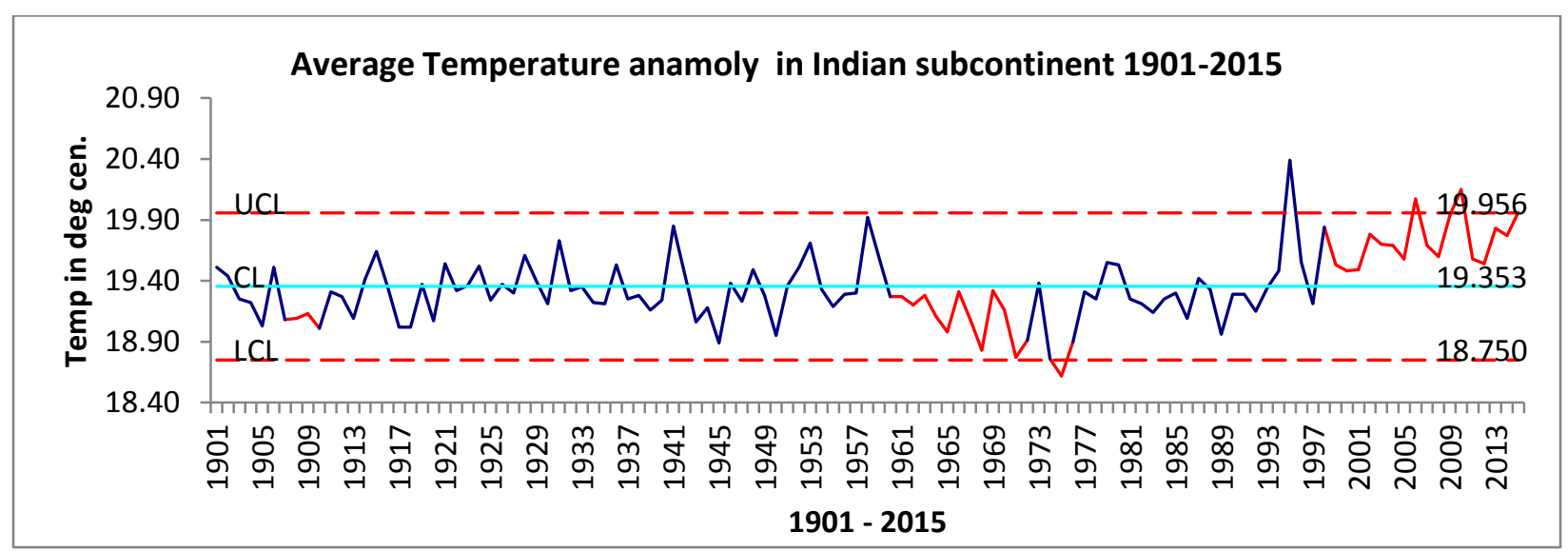

Fig 6 (a):- Average temperature anomaly of Indian subcontinent for the period 1901 to 2015 


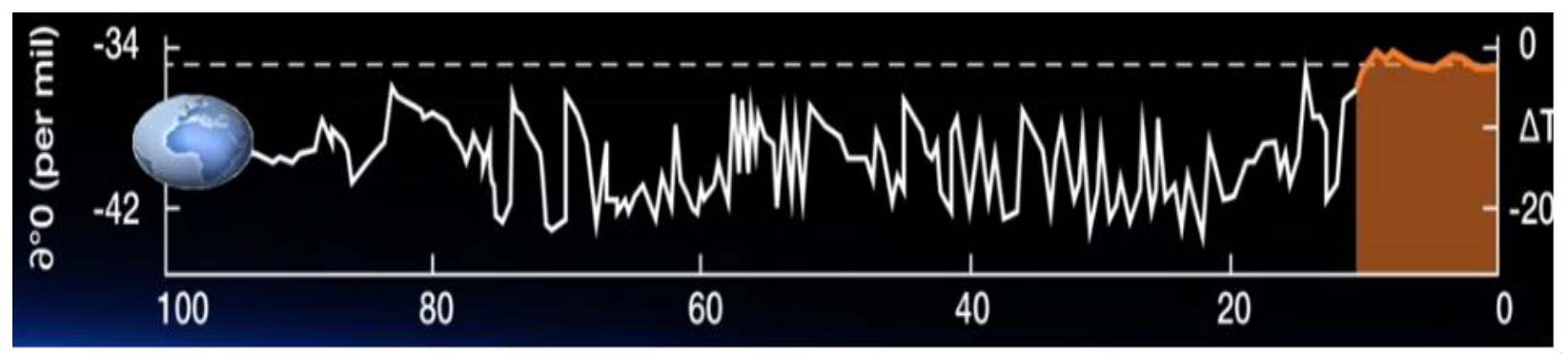

Fig 6(b):- Temperature anomaly of earth in K-years before present (Johan Rockstorm, Stokholme University)

\section{Heat waves and Lightening:-}

There is dynamic rise in temperature with a maximum in the year 2012 in $21^{\text {st }}$ century. The ten top ranked Heat Waves death in the globe's history in $21^{\text {st }}$ century are 71130 in Europe (2003), 55,736 in USSR (2010),3,418 in Europe (2006),2,541 in India (1998), 1,826 (probable) in India (2015), 1,693 in U.S. and Canada (1936), 1,260 in U.S. (1980), 1,210in India (2003) and India 1,030 in (2002). The figure indicates that frequent heat waves have hit India in the early $21^{\text {st }}$ century. However India had the hottest year, 2016 and the hottest day with highest mercury of $51^{\circ} \mathrm{C}$ in Rajasthan at Phalodi on 23rd May 2016. Lightening in stratosphere, electro-dynamic anomalies and thermal irregularities have increased the trend of heat waves and lightening deaths in India (Fig 7).

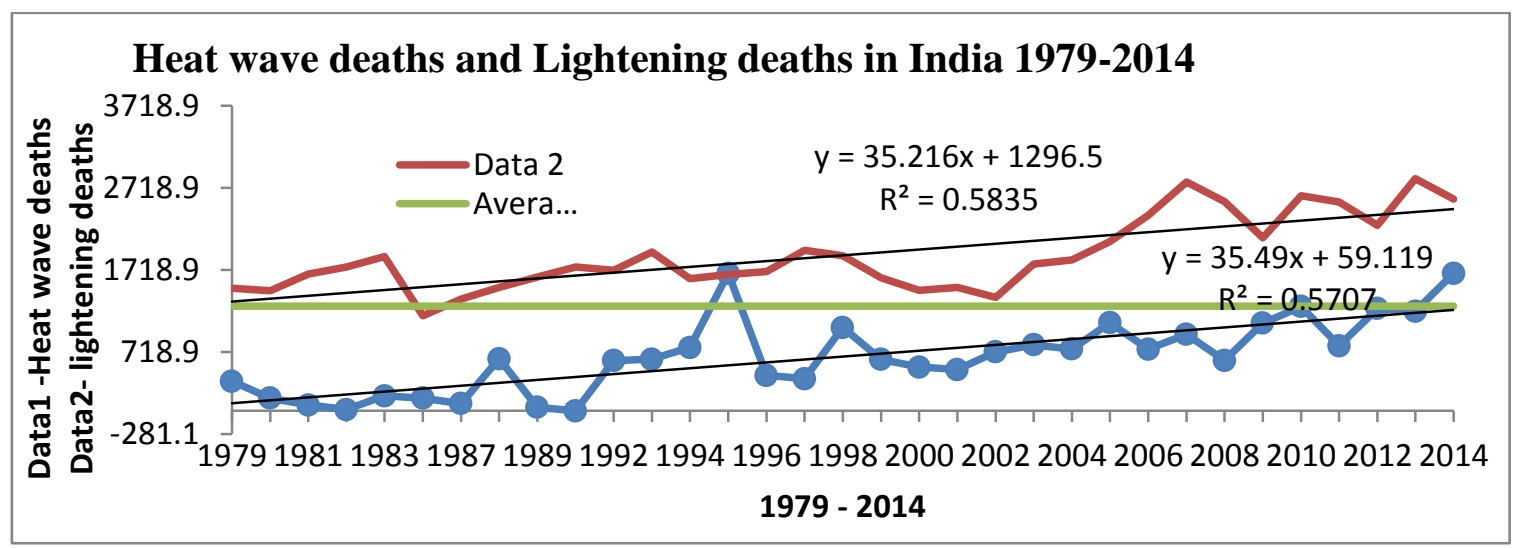

Fig 7:- the heat wave and lightening fatalities are having rising trend from year 1979 to 2014

Tornadoes and thunderstorms are common during pre-monsoon in central, north and north-east India causing loss to properties, crops and fatalities which is related to the acceleration of the new epoch. The highest recorded mortality was 500 in tornado at Dhaka in 1977 and causalities of 6000 people.

\section{GHG gasses:-}

$\mathrm{CO}_{2}$ is one of the major greenhouse gases (GHG's) that traps heat in the atmosphere which reached maximum record in 2012. It is continuously accelerating and drifting upward which can drive hydro-meteorological changes and will bring variations in our planet in future during the new epoch (WMO report 2013). GHG's are natural and essential for humans. Methane $\left(\mathrm{CH}_{4}\right)$, carbon dioxide $\left(\mathrm{CO}_{2}\right)$, oxides of nitrogen (mainly $\mathrm{N}_{2} \mathrm{O}$ ), hydro-fluorocarbons (HFCs), per-fluoro-carbons (PFCs), trifluoro-methyl-sulphur-penta-fluoride $\left(\mathrm{SF}_{5} \mathrm{CF}_{3}\right)$, sulphur hexa-fluoride $\left(\mathrm{SF}_{6}\right)$ and Water vapor are the main causes for global warming. Since 1950, India has produced roughly 4, 2 billion tons of carbon respectively. The annual generation of carbon per capita in India was 1.9 tones which was less than that in China and USA but it had increased three times since 1990 and doubled by 2009 to 2014 .

Effects of $\mathrm{CO}_{2}$ :-

The natural carbon cycle is slower than the human-induced climate changes. According to Dana Nuccitelli (2016), $\mathrm{O}^{\prime} \mathrm{Day}^{[45]}$ from NOAA, $\mathrm{CO}_{2}$ level reached maximum in the year 2015.The residence time of $\mathrm{CO}_{2}$ is 4-15 years, which is very short (IPCC). Then reason for short residence time of $\mathrm{CO}_{2}$ in the atmosphere and increasing trend negates the fact of its increase in the atmosphere contradicting the increase carbon level. Cawley Gavin ${ }^{[46]}$ reported that the temperature of the earth have risen to $1.5-3^{\circ} \mathrm{C}$. It is estimated that the rise in temperature on earth 
surface shall be warming the atmosphere over the coming decades and about 30 billion tons shall be pumped by the earth to warming over the coming decades and pumping about 30 billion tons of $\mathrm{CO}_{2}$ shall be pumped by the earth to the air every year. Debating on $\mathrm{CO}_{2}$ emission and climatic change, the Climate Commission, Australia, reported their climate change in 2001-2010 of $21^{\text {st }}$ century as 'critical'. In India and in the globe the CO2 emission is raising gradually Fig 8 (a) and Fig 8 (b).

GHG gases are classified as brown (industrial) Green (from inland vegetation), Blue (oceanic biomass) and black (incomplete combustion of fossil fuels) Leahy Stephen, (2007) ${ }^{[47]}$. The status of $\mathrm{CO}_{2}$ was @ $379 \mathrm{ppm}$ in 2005 whereas it was $283 \mathrm{ppm}$ before the industrial revolution i.e. in 18th century. Concentrations of $\mathrm{CO}_{2}$ in the atmosphere were $142 \%$ higher than what they were before the Industrial Revolution (WMO greenhouse gas bulletin2013).In this new age, the $\mathrm{CO}_{2}$ level shall be high to give many marine organisms less time to adapt. Some marine creatures are growing thinner shells or skeletons that will play a crucial role in the biodiversity and in food chain.

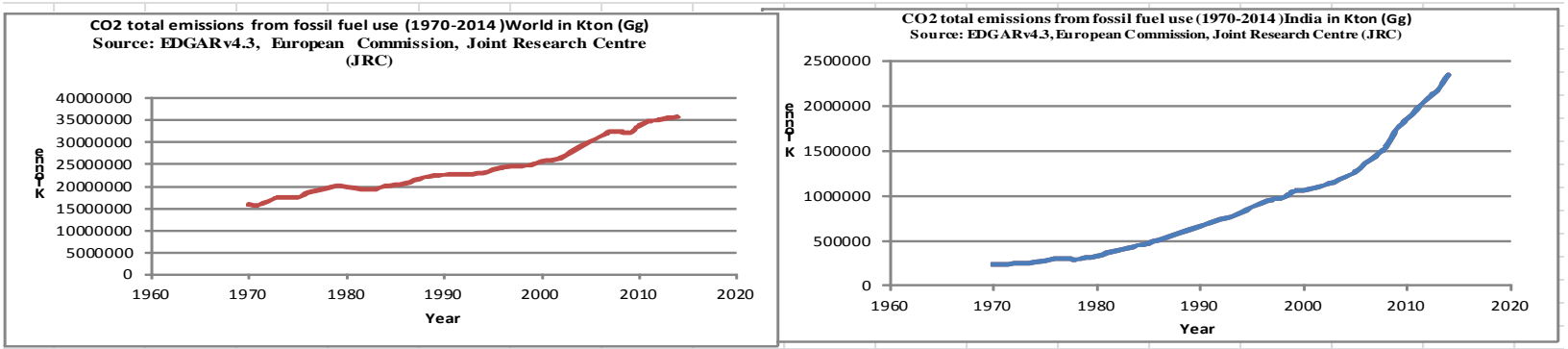

Fig 8 (a):-Global $\mathrm{CO}_{2}$ emission global annual trend Fig 8(b) $\mathrm{CO} 2$ emission in India annual trend (1970 to 2014)

\section{Geohydrology:-}

Geohydrology potential in ground water table (GWT) in India have changed due to over exploitation as $60 \%$ land is rain fed. Fifteen percent of India's groundwater resources are overexploited without retrospective recharge. This shall invoke subsidence. Growing population, comfortable life styles, modern utilities, services and industries demand shall urge to draw more GW with less recharge hence more depletion and increased salinity intrusion along coast.

\section{De-glaciation:-}

Westerly Jet dominated NW Himalayas and Karakoram ranges are stable. The NE Himalayan glaciers are retreating due to erratic SW monsoon and global warming. At $2-4^{0}$ rises in temperature, this shall increase discharge in Ganga, Indus and Brahmaputra. Pervasive mass losses in Himalaya and drops in snow cover in glaciers shall accelerate during the $21^{\text {st }}$ century and cause water scarcity, hydropower deficit, and variability in seasonal flows from HinduKush and Himalaya in India (IPCC AR -4). The rivers from Himalaya's shall enhance the frequency and intensity of floods affecting the huge coastal population of 62 million. The ice mass in poles is melting and sheet moving to warmer region since last two decades loosing 215 Giga tones annually and add to mean sea level rise along the coasts (IPCC AR-5).The huge sediment reaching the deltas shall protrude and distort the Ganga-Brahmaputra delta prominently during great acceleration of Anthropocene.

\section{Mean sea level rise:-}

High emission, movement of ice sheets in a warning region, melting of ice in Himalayan glaciers and the arctic region are signs of the age. Summer urban flooding along low lying coastal areas has been aggravated. There has been change in configuration and dimensions of estuaries/lagoons and positioning of their tidal inlets. The coastal erosion, accretion and submergence have become rampant. The World Watch Institute (2000) has reported that the influences are due to land ice melting (42\%), ocean warming (35\%) and $12 \%$ from inland water.

Coromandel coast line in India has exhibited four to five strand lines during the period of Holocene. Ministry of Earth Sciences, India is focusing on MSL rise as there was increase of submergence, erosion and coastal flooding along the coasts of India. Saltwater intrusion and back water propagation have increased both surface and ground waters. It has impact on mangroves, salt marshes and sediment stratigraphy in lagoons. The SLR reported by Nicholas (2010)is @ $3.3 \pm 0.4 \mathrm{~mm} /$ year in the globe. But in Indian scenario the SLR was 1.2, 1.75,1.09 and $5.74 \mathrm{~mm} /$ year along coasts of Mumbai, Kochi, Visakhapatnam and Kolkata respectively (Unikrishnan et al ,2006 ${ }^{[48]}$ ). 
Both the west and east coast of India have been worst affected by disturbances and storm surges Fig 9, Shetye et al, $(1990)^{[49]}$ and Mishra et al $\left.(2014)^{[50]}\right)$. Submergence from flash flood and coastal erosion has made the life of poor worst in islanders of India.

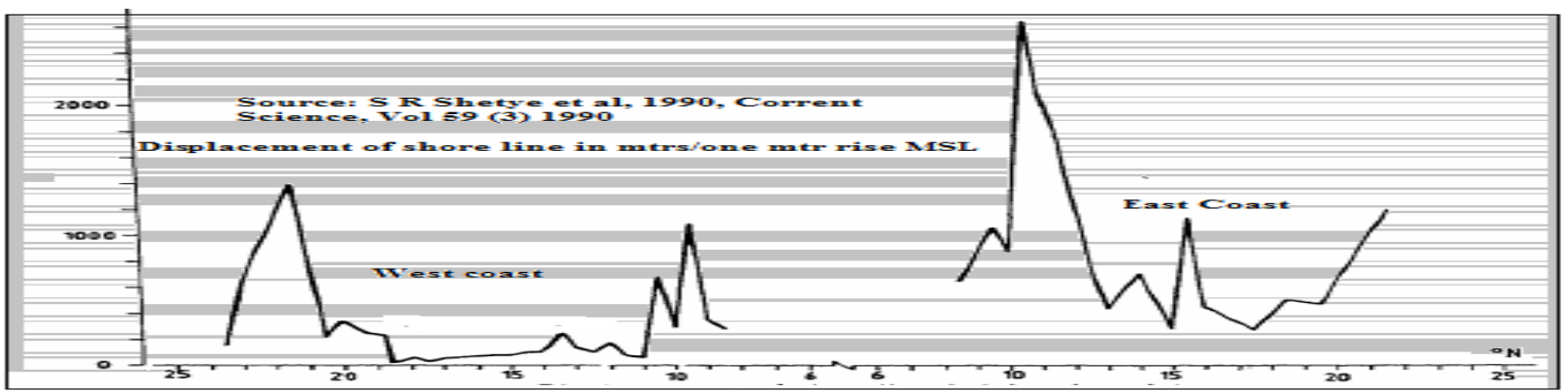

Fig 9:- Shore line shift of east coast and west coast of India per one meter rise of mean sea level

\section{Bio-centric Anthropocene:- \\ Deforestation:-}

Deforestation goes on unabated in tropical forests of India. But study reveals that greenness of vegetation is rising across the globe capturing about $750 \mathrm{MMT}$ of $\mathrm{CO}_{2}$ annually and reducing $24 \%$ of worlds GHG emission. $33.33 \%$ of India's tropical deciduous forests shall become evergreen due to heavy rainfall in patches of high temperature zone IPCC AR-5 (2014) ${ }^{[51]}$. Deciduous forests shall accelerate but growth shall slowdown by demographic pressure.

\section{Pollution of water air and soil:-}

Polluted and contaminated air, water and soil and climatic changes shall enhance the risk of water borne and vector borne diseases, mental disorders, post traumatic syndromes, more heat strokes and disaster prone mortality rates. Economic climate resilience actions, the storage reservoirs and integrated basin management can ameliorate the problem.

\section{Ocean acidification:-}

About (30\%) $\mathrm{CO}_{2}$ is dissolved in ocean and increases water temperature and decreases alkalinity of ocean water: $\mathrm{H}_{2} \mathrm{O}+\mathrm{CO}_{2}+\mathrm{CO}_{3} \mathrm{~A}=\mathrm{H}_{2} \mathrm{CO}_{3}$. NOAA-2010 have reported that more acidic sea water and the carbonic acid formed shall disturb the ability of marine plants and animals to thrive, http://www.noaa.gov/resourcecollections/ocean-acidification. Recently micro-planktons in the ocean are responsible for the sequestration of 25$50 \%$ of the carbon which is cumulating ocean acidification. The plankton plays vital role in atmospheric carbon dioxide $\left(\mathrm{CO}_{2}\right)$ fixation at lower levels. Otherwise oceanic acidification would have been a peril to environment. World Bank has predicted that $1.4^{0} \mathrm{C}$ rise from present temperatures (in 2030) shall reduce coral growth and at $2.4^{0}$ Criseshall either dissolve or dry up them. http://www.Worldbank.org/en/news/feature/2012/11/18/Climatechange-report. In India risk zones have developed and shall proliferate to the Andaman, Nicobarand Lakshadweep Islands, Palk Bay and Gulf of Manner, and all lagoons along the coasts.

\section{World Hunger and Food Security:-}

Increased droughts and desertification have adversely affected agriculture and livelihoods leaving aside warm weather crops. Melting of glaciers is worsening floods in north India. Rice cultivation is less productive in Nepal forcing the farmers to change their cropping pattern. Advanced agriculture has encouraged swapping of crops by replacing genetically modified crops in last 30 years to combat the food security. .Economic and technology advancement for growing population in India has increased average rice production (6\% higher i.e. $75 \mathrm{MT} / \mathrm{Ha})$ whereas the wheat production in north India have reduced because of rise in temperature from the year 2000.Rise in temperature, intrusion of saline water in coastal zone and erratic monsoon have reduced crop yields and enhanced food insecurity. India shall have agricultural loss of $10 \%$ to an extent US $\$ 7$ billion if adequate climatic resilience measures are not taken. There shall be stress on food specially the wheat production IPCC AR-5, WRG II,(2014). ${ }^{[51]}$ 


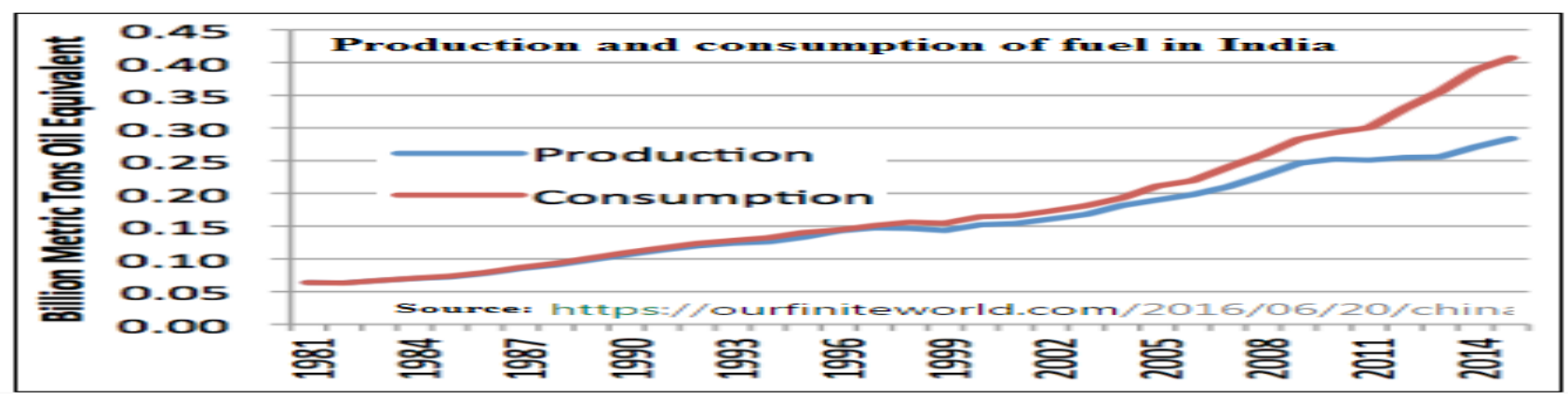

Fig 10:- Production and consumption of different fuel in India between the years 1981 to 2014

\section{Energy and water security:-}

Electrical energy of 92378.38 MW (thermal),4560 MW (nuclear power) and 37567.40MW(hydropower) was generated in India (CEA,2010). Paucity of water in rivers has reduced hydropower generation. The mushroom growth of thermal power plants have increased $\mathrm{CO}_{2}$ level and affected energy security. The commercial energy consumption in India is less in comparison to other countries. It had risen from 1965 by $9 \%$ whereas it was $19.4 \%$ in 2000 (Tata Energy Research Institute report, 2000). In the process of great acceleration there shall be diminishing supply of fossil fuels which should exacerbate production and use of biofuels. Energy demand is higher than the production, and crisis will be more in India in the Anthropocene (Fig 10)

Erratic monsoon, demographic growth, urbanization and industrialization could not satiate growing demand of water and augment water stress. Erratic SW-monsoon shall bring more floods in Sept whereas longer dry spell in the month of May shall affect the fresh water availability from peninsular rivers. Drinking water shall be so precious that apprehension of third world war may be due to water.

\section{Synthetic Life:-}

Recent advances in molecular and genetic researches could develop artificial genome; bacterial chromosomes which can replace DNA in a bacterium producing new protein sets which can bring revolution in genetic engineering as part of the great acceleration where life span shall be multifold, Venter J. C. $2010^{[52]}$. Now the Institute of Genomics and Integrative Biology can produce genomes. The age of synthetic life has started in India.

\section{Health hazards:-}

Major health impact due to climatic disgrace, population growth and anthropogenic activities shall enhance pediatric mortality, Vector borne diseases (especially due to mosquitoes), Hearts and lungs diseases, infectious and noncommunicable diseases Vaughan et al $(2016)^{[53]}$.. The endemic, outbreaks and epidemics throughout the land and ocean based wildlife have become unwarranted due to disruption of natural ecosystem. Pests, Vector diseases and immunity based diseases have aggravated both among the humans and the wild life. The contaminated water and stagnated urban floods shall exacerbate diarrheal diseases but effective management shall reduce the DALYs rate Singh et al 2012 ${ }^{[54]}$. Some new genera of malicious vectors and microorganisms have come up in the epoch which shall cause unnatural deaths and many species will be endangered or extinct. Use of hormones for early high yielding grains, vegetables and meat shall make the human based Anthropocene to be apocalyptic. Revkin Andrew, $(2011)^{[55]}$ told that a type of Cyanobacteria had put an end to life and species 2billion years BP in past.

\section{Socio-economic-political:-}

Socio economic conflicts, poverty, segmented demography have forced the Indians to a continuous brain drain to western countries since 1980's. Regional cooperation on interstate and intercontinental disputes with raised demand for water have started from 1970-1980.Some crucial turns have resulted in man-made political and economic issues. Global trade policies are making the poor to be poorer. There shall be 0.2 to $2 \%$ loss to annual global income on $2{ }^{\circ} \mathrm{C}$ rise in temperature. But higher increase can bring calamity IPCC WR II, AR-5,(2014).

\section{Migration, education and skill:-}

India is switching from agro-base society focused on production to a consumerist society. The impact of migration, education and skill has brought us the social mobility, both linear vertical and spatial. Migration changes life style, 
GDP and the emission. The migration from rural to urban areas has been studied and the rate of migration was 314.5 million as per 2001 Census in India in quest of education and skill development which is a very high figure.

\section{Gender based changes:-}

The women in India have less resource to cope and adapt with the climate and biologic reasons than men. They are deprived, poor and unequal which undermines their social and capital stand in the orthodox family in India. There is increase in gender based violence where women are the worst vulnerable. The unprivileged women are more in rural settlements than in urban. The gender ratio in India in last few decades may be one of the reasons for decline of population.

\section{Gross Domestic Product:-}

Global energy-related changes, $\mathrm{CO}_{2}$ emissions and the influencing factors for climate changes as per KAYA identity (1971 to 2009) are at $79 \%$ population growth increase in per capita GDP and energy emissions are $106 \%$ and $105 \%$ respectively. Increase of GDP of India (Fig 11) from year 1985-86 with higher increase in emissions of $\mathrm{CO}_{2}$, establishes the fact that the Anthropocene is in vogue in India.(Source: IEA loc.cit.http://www.feasta.org/wpcontent/uploads/2013/02/Economic_growth_Population_growth.pdf

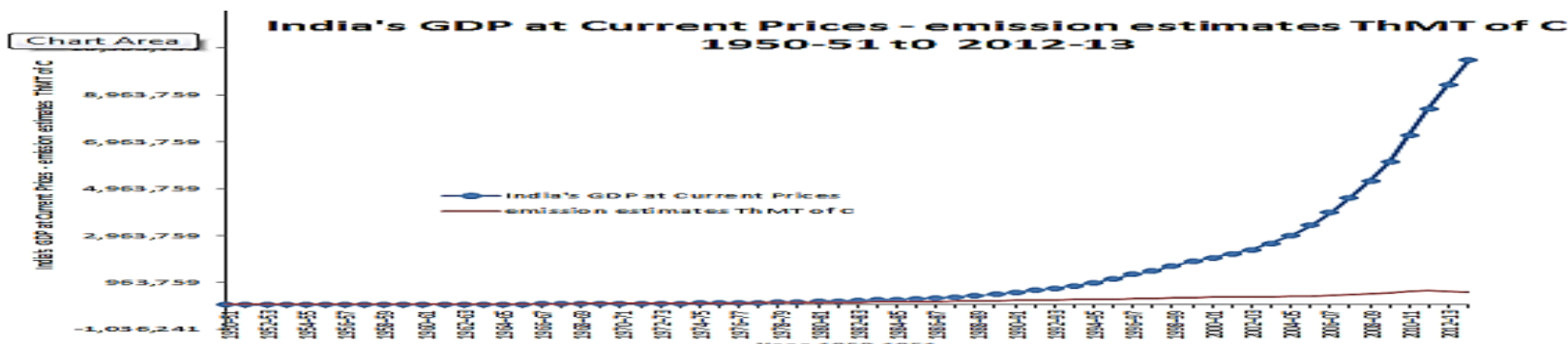

Fig 11:- GDP growth of developing country India for the period 1950-2013 and 1986 is year of increase

Increased GDP growth (Fig 12) and retardation of rural settlement shall increase urbanization and industrialization which shall augment GHG's emission. Gross domestic product in India and its nominal values and purchasing power parity have been studied and the base year for calculation of purchasing power was considered to be the year 2000 which is the point of inflection of the curve Fig 11.

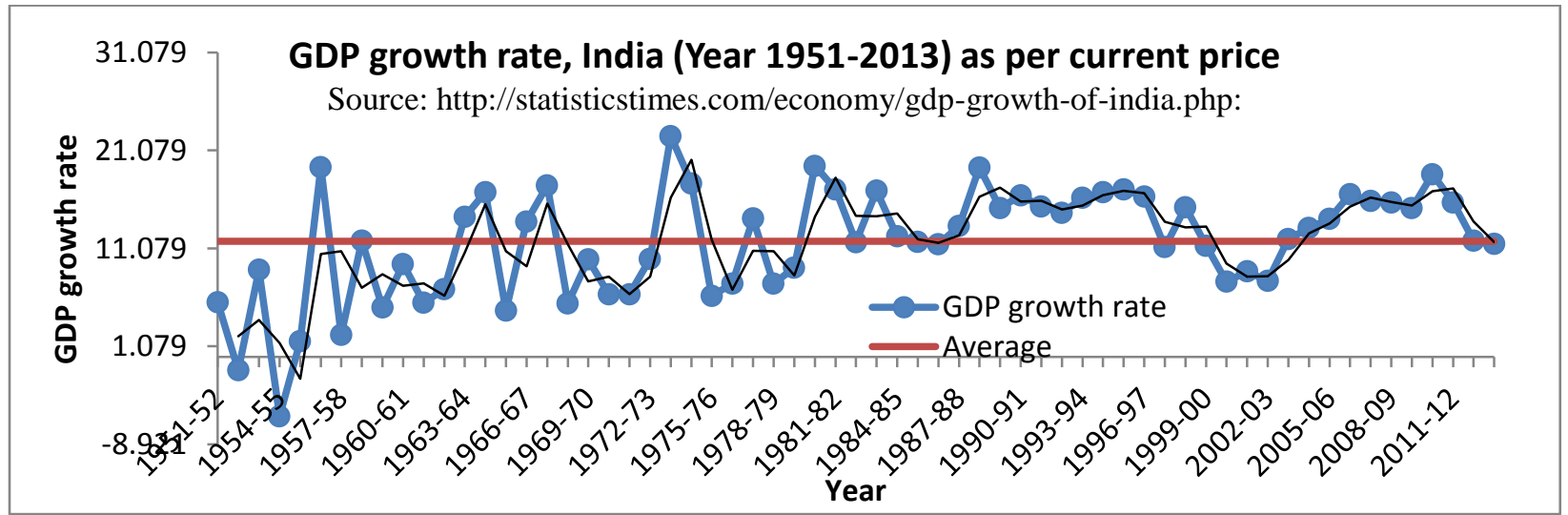

Fig 12:- The time series and moving average curves for GDP growth of India (1951-2013),

\section{Geologic Evidences:-}

Instantaneous causalities and fatalities only occur due to earthquakes, tsunamis, landslides and volcanic activities. First 2decades of $21^{\text {st }}$ century have signaled that the living kingdom have to pay huge losses due to geological extremes. India is safe towards volcanic activities as there is only one active volcano in Andaman Islands. But the impact of earth quakes, tsunamis, limnology, and lithology changes are common in Indian subcontinent. 


\section{Limnology:-}

Limnology changes have disturbed the fauna and flora of water bodies, reservoirs, lakes, back waters and lagoons other than bay of Bengal and Arabian sea of India in post-Holocene, pre-Anthropocene and even during the great acceleration period. The physic Chemical parameters, rising of bed, squeeze of flood plains of rivers and sedimentation, reduced stratification and downsizing by volume of lakes/lagoons are observed. Dal lake Kashmir, Pichola lake Udaipur,Vena Lake Mahabaleswar, Koleru Lake (Andhra Pradesh), Chilika and Pulikat Lagoons were affected during the great acceleration of the Anthropocene. Construction of dams, barrages and weirs during the period of Anthropocene have retained the sediment at back and the deltas of India are in a state of sinking, shrinking and subsidence (Sivesky et al, 2009 ${ }^{[56]}$, Gupta et al 2012 ${ }^{[57]}$, Mishra S P, 2016 ${ }^{[58]}$ ).

\section{Lithology:-}

Out of 5200 types of minerals,(International Mineralogical Association), 208 minerals are of human origin formed due to great oxidation events in dump yards of mining area, smelter plant's inner walls, weathered slags, mine fire zone, walls of tunnels and debris of plastic wastes. Artificial stones, wastes from building demolitions, industrial scarps, cinder blocks and toxic radioactive byproducts have formed layers and shall be the lithological imprints of future as Anthropocene minerals. Plastic debris and trashes on beaches resulting from human activity and Tsunami activity shall form with sediment, fragments of basaltic lava and organic wastes/ shells to form a new rock Clastic plastiglomerate which will remain as a stratum and can be a future earth's rock record, as a geographic mark.

Sea water intrusion due to decreasing inland flow has altered salinities in the deltas/estuary soils. The elite, chlorite, and $\mathrm{Na}+$ contained montmorillonite soil have increased and $\mathrm{Ca}++\mathrm{Na}+$ mixed montmorillonite soil has decreased. $\mathrm{Na}+$ mixed montmorillonite is major soil in swamps and elite in lagoons/ backwaters of the soil in east coast of India is major paleo changes during Anthropocene.

\section{Seismicity and Tsunamis:-}

The number of earthquakes of magnitude $>7$ in Richter scale has occurred in the $21^{\text {st }}$ century till $10^{\text {th }}$ Feb 2017 in the globe. The major earth quakes that had caused heavy fatalities and casualties in $19^{\text {th }}, 20^{\text {th }}$ and $21^{\text {st }}$ century were of magnitude $>7.0$ in Richter scale. India was under the attack of the tsunamis from mid of $17^{\text {th }}$ century in record. The intense upsurges recorded were $12 \mathrm{~m}$ and $10 \mathrm{~m}$ in case of Makran Tsunami $27^{\text {th }}$ Nov 1945 and Sumatra tsunami $26^{\text {th }}$ Dec 2004. The seismicity can alter an age or epoch because of its devastating impact as told by geologists in great dying period 200-250my BP. The extreme events during Anthropocene are in Table 2.

Table 2:- The changes and extreme events in different stages of the Anthropocene epoch in Indian Subcontinent

\begin{tabular}{|c|c|c|c|c|}
\hline Decade & Changes / extreme events & Deaths/casualties & Losses & Remarks \\
\hline 2000-3000 BP & $\begin{array}{l}\text { increased rainfall, cooler } \& \text { humid } \\
\text { climates, the beech forests }\end{array}$ & $\begin{array}{l}\text { The civilization } \\
\text { collapsed }\end{array}$ & $\begin{array}{l}\text { Decline of Harappa } \\
\text { /Mohenjo-Daro age }\end{array}$ & \\
\hline \multicolumn{5}{|l|}{ 1700-1850 AD } \\
\hline $\begin{array}{l}1769-70 \mathrm{AD} \\
1783-84 \\
1791-92 \\
1819 \\
1837-38 \\
\end{array}$ & $\begin{array}{l}\text { Great Bengal Famine } \\
\text { Chalisa famine } \\
\text { Dojibara famine } \\
\text { Gujarat Earthquake } \\
\text { Agra Famine }\end{array}$ & $\begin{array}{l}10 \text { million } \\
11 \text { million } \\
11 \text { million } \\
0.02 \text { million } \\
0.8 \text { million } \\
\end{array}$ & $\begin{array}{l}\text { Loss indigo plants } \\
\text { for dye and opium } \\
\text { poppies destroyed }\end{array}$ & $\begin{array}{l}\text { Manmade(Wiki } \\
\text { pedia) }\end{array}$ \\
\hline \multicolumn{5}{|l|}{ 1851-1945 AD } \\
\hline $\begin{array}{l}1860-61 \\
1865-67 \\
1868-70 \\
\end{array}$ & $\begin{array}{l}\text { Upper Doab famine } \\
\text { Orissa famine } \\
\text { Rajputana famine }\end{array}$ & $\begin{array}{l}2.0 \text { million } \\
1 \text { million } \\
1.5 \text { millions }\end{array}$ & $\begin{array}{l}\text { I Punjab/ Rajputana } \\
\text { Bihar; Bellary and } \\
\text { Ganjam }\end{array}$ & $\begin{array}{l}\text { https://en.wikipedia. } \\
\text { org/wiki/Timeline_of } \\
\text { major_famines_ }\end{array}$ \\
\hline $1881-90$ & Odisha famine & 1.5 million & & \\
\hline $\begin{array}{l}1896-97 \\
1897\left(12^{\text {th }} \text { June }\right) \\
1899-1900\end{array}$ & $\begin{array}{l}\text { Indian famine } \\
\text { Assam earthquake } \\
\text { Indian famine }\end{array}$ & $\begin{array}{l}5.0 \text { millions } \\
0.0015 \text { millions } \\
>1.0 \text { millions }\end{array}$ & Richter Scale 8.3 & In British territory \\
\hline $1905\left(4^{\text {th }}\right.$ April $)$ & Kangra earth quake & 0.0019 millions & Richter Scale 7.5 & In British territory \\
\hline \multicolumn{5}{|l|}{ 1951-1980 AD } \\
\hline $1961-70$ & 1970 Bhola cyclone & 0.5 million & \$86.4 million (1970) & Bangladesh \\
\hline $1971-80$ & Cyclone Andhra, India, 1977 & 10,000 people & 40,000 cattle deaths & \\
\hline 1980-2017 & The great Acceleration & & & \\
\hline $1984,19^{\text {th }}$ Oct & Bhopal Gas tragedy & 20000 deaths & 5lakhs affected & \\
\hline
\end{tabular}




\begin{tabular}{|c|c|c|c|c|}
\hline $\begin{array}{l}1993\left(29^{\text {th }} \text { Sept }\right) \\
1998\end{array}$ & $\begin{array}{l}\text { Latur Earthquake } 1993 \\
\text { Super cyclone Odisha, India 1999, } \\
\text { Heat waves }\end{array}$ & $\begin{array}{l}\text { 7,928 people died } \\
0.002 \text { millions } \\
0.0013 \text { millions } \\
\end{array}$ & $\begin{array}{l}30,000 \text { injured } \\
\text { Max mercury } \\
\text { reached } 45 \text { to } 50^{\circ} \mathrm{C} \\
\end{array}$ & $\begin{array}{ll}\text { Prominent, El Niño } \\
\text { Transition } \\
1998\end{array}$ \\
\hline $\begin{array}{l}2001\left(26^{\text {th }} \text { Jan }\right) \\
2004\left(26^{\text {th }} \text { Dec }\right) \\
2005\left(24^{\text {th }} \text { July }\right) \\
2005\left(8^{\text {th }} \text { Oct }\right) \\
2010 \\
2010 \\
2010 \\
2010\end{array}$ & $\begin{array}{l}\text { Bhuj, Earth quake, India((M 7.6) } \\
\text { Great Sumatra earthquake and } \\
\text { Tsunami (M9.3) } \\
\text { Teressa Island, Andaman (M7.3) } \\
\text { Kashmir earthquake (Pak/ India) } \\
\text { Asian Monsoon displaced west } \\
\text { The snow retreat and recorded snow } \\
\text { melt reduced } \\
\text { Cancer death (age 30-69) }\end{array}$ & $\begin{array}{l}20000 \text { deaths } \\
280000 \text { deaths } \\
\text { Least deaths } \\
\text { Well adminstered } \\
74661 \text { deaths } \\
\text { 138,366 people } \\
\text { 15,000 people } \\
\text { 1600people } \\
\text { 5,56,400 people }\end{array}$ & $\begin{array}{l}0.63 \text { million affected } \\
10 \mathrm{~m} \text { high surges, } \\
\text { land form distorted } \\
\text { No reported trauma } \\
\\
\text { snow area by } \\
4.9 \text { million sqkm }\end{array}$ & $\begin{array}{l}\text { Prominent, El Niño } \\
\text { to La Niña } \\
\text { Transition (ENSO), } \\
\text { heavy rainfall } \\
\text { R. Prasad, http:// } \\
\text { www.thehindu.com/s } \\
\text { ci-tech/health }\end{array}$ \\
\hline 2011-17 & $\begin{array}{l}\text { Uttarakhand/ H.P., Rain/ Flood } \\
\text { India } 2013 \\
\text { Hiayan typhoon, Philippines, } 2013 \\
\text { But Phailin storm India, } 2013\end{array}$ & $\begin{array}{l}4094 \text { people } \\
\text { 10,000 dead but } \\
\text { 21people(only). }\end{array}$ & $\begin{array}{l}>9 \text { million affected } \\
>9 \text { million affected }\end{array}$ & \\
\hline
\end{tabular}

\section{PHA's and NEO's:-}

According to NASA, exo-planet Alien asteroids of smaller size $(<25 \mathrm{~m})$ get burnt in the Earth's hemisphere and cause inconspicuous damage. Meteors of size $(>25 \mathrm{~m})$ slam earth at a frequency of 2,000 years or so and damaged an extensive area significantly. Asteroids of very large size are hostile to mass extinction and earths civilization ( https://www.nasa. gov/ mission_pages/ asteroids /overview/fastfacts.html). The impact and the potential effects of potentially hazardous asteroids (PHAs) or near earth objects (NEOs) are location specific and caused damages depending upon angle of hit, velocity of slamming and the size of the alien Table 3.

The Permian-Triassic asteroid in 200-250 million years BP and the Hephaistos or SL9 of 65-66 million years BP are responsible for the mass extinction during transit period of Permian-Triassic (P-Tr) eon and Cretaceous and Tertiary (K-T) era and believed to end the Permian period and cretaceous period by destructing $90 \%$ of species and delaying the process of evolution by millions of years.

Table 3:-List of exo-planet Alien, PHAs and NEO pre Anthropocene and post Anthropocene disasters

\begin{tabular}{|c|c|c|c|c|c|}
\hline \multicolumn{6}{|c|}{ Major alien asteroids slammed earth before 2016} \\
\hline Year & Place of strike & Boundary of era & size & Effect & \\
\hline $\begin{array}{l}\text { 200-250 my BP } \\
\text { (great dying) }\end{array}$ & Controversy, & $\begin{array}{l}\text { Paleozoic to Mesozoic } \\
\text { Era, Triassic (P- } \\
\text { Tr) extinction event } \\
\text { (fullerenes/buckyballs) }\end{array}$ & $9 \mathrm{Km}($ & $\begin{array}{l}\text { Global warming, } \\
90 \% \text { mass extinct } \\
70 \% \quad \text {-terrestrial } \\
\text { vertebrate }\end{array}$ & $\begin{array}{l}\text { G. Jeffrey Taylor, } \\
\text { http://www.psrd. } \\
\text { hawaii.edu/Feb01/perm } \\
\text { ianImpact.html }\end{array}$ \\
\hline 65-66 my BP & $\begin{array}{l}\text { Yucatan Peninsula, } \\
\text { Chicxulub crater, } \\
\text { Mexico }\end{array}$ & $\begin{array}{l}\text { Cretaceous-Paleocene } \\
\text { extinction event. } \\
\text { (Hephaistos or SL9) }\end{array}$ & $10 \mathrm{Km}$ & $\begin{array}{lr}\text { Global } & \text { warming, } \\
\text { dinosaurs } & \text { large } \\
\text { Extinct } & \\
\end{array}$ & $\begin{array}{l}\text { https://www.psi.edu/ep } \\
\text { o/ktimpact/ ktimpact. } \\
\text { html }\end{array}$ \\
\hline 3.3 my BP & Argentina & $\begin{array}{l}\text { Cretaceous-Tertiary } \\
\text { (KT) extinction }\end{array}$ & $\begin{array}{l}37-58 \\
\mathrm{~km}\end{array}$ & $\begin{array}{l}\text { extinctions/ global } \\
\text { cooling trend }\end{array}$ & \\
\hline 50000years BP & Arizona $(\mathrm{N})$ & $\begin{array}{l}\text { Pleistocene180 } \mathrm{m} \\
\text { deep, } 1.2 \quad \mathrm{~km} \\
\text { diameter } \\
\text { shaped depression }\end{array}$ & $30 \mathrm{~m}$ & $\begin{array}{l}\text { impact of a } \\
100,000 \text {-ton iron- } \\
\text { nickel meteorite }\end{array}$ & $\begin{array}{l}\text { https://astrogeology.usg } \\
\text { s.gov/facilities/meteor }\end{array}$ \\
\hline 1490AD & $\begin{array}{l}\text { Chiling- } \\
\text { yang(China) }\end{array}$ & $\begin{array}{l}\text { Huge number of } \\
\text { meteorites of stones. } \\
\text { covered } 4-5 \text { cities of } \\
\text { China }\end{array}$ & $\begin{array}{l}\text { Scatte } \\
\text { red } \\
\text { stones }\end{array}$ & 10000 people death & $\begin{array}{l}\text { http://articles.adsabs.har } \\
\text { vard.edu//full/1994Meti } \\
\text { c..29..864Y/0000867.00 } \\
\text { 0.html }\end{array}$ \\
\hline 1908 & $\begin{array}{l}\text { Tunguska, Siberia, } \\
\text { Exploded } 10 \mathrm{~km} \\
\text { above ground }\end{array}$ & $\begin{array}{l}\text { Breaking up of large } \\
\text { meteorite } \\
50 \mathrm{~m}, 2150 \mathrm{~km}^{2} \text { ruin }\end{array}$ & & $\begin{array}{l}\text { releasing energy in } \\
\text { the atmosphere } 10- \\
15 \text { megatons }\end{array}$ & $\begin{array}{l}\text { http://news.nationalgeo } \\
\text { graphic.com/news/2007 } \\
\text { /11/071107-russia- }\end{array}$ \\
\hline
\end{tabular}


Major anthropogenic fatalities due to population explosion are accidents, stampedes, wars, Naxalite activities and many such. Those major fatalities were absent during Holocene epoch in India.

Present and future impacts of Anthropocene epoch in India:-

Present globe is influenced by human agents overriding the catastrophic nature and extremes of sun earth geometry. If present trend continues, $75 \%$ species will become extinct in the next few centuries on the earth Vaughan $(2016)^{[53]}$.The new age Anthropocene is still under debate as to whether it is a part of Holocene or a new one.

Melting of ice in Himalayas due to high temperature shall increase summer flow in perennial northern rivers like Sindh, Ganges and Brahmaputra and many others. Flash flood in Kedarnath (2013) was due to over topping of Chourabari lake killed 5700 people. The 427 dams proposed to be constructed in Himalayas may extinct the species, increase more landslides and flash floods in Siwalik range and lower Himalayas.

Outbreak of vector, immune deficiency diseases, effect of pests and water borne diseases shall increase during Anthropocene (Ex: malaria, kala-azar , dengue and chikungunya Japanese encephalitis etc.. Some deadly diseases of Holocene epoch shall be completely eradicated in India. The disability-adjusted life year (DALY) is the years lost due to disability, ill-health, or early death shall reduce in comparison to the globe by $46.6 \%$, Singh et al (2012) ${ }^{[54]}$.Smoking, drugs, and alcohol shall certainly add to the DALY rate.

High yield of low paddy due to improved genetic advancement and less production rate of wheat is highly risked. The insufficiency in agricultural yield, milk and protein foods due to increased demography shall have negative impact on human health leading to malnutrition, if not addressed in time. Medication for premature growth shall be apocalyptic.

Biodiversity impacts: A large number of invasive species creep into the water bodies, lagoons and marine system causing myriad impacts on human health. Marine water snails devastate the vegetation in the coast and transmit schistosomiasis, vectors proliferate diarrheal diseases. Coastal erosion and low lying area inundation likely to affect poor people by Anopheles sundaicus (Diptera: Culicidae). A brackish water breeder mosquito vector of malaria shall widespread which was confined in Andaman and Nicober Island only. MSL rise shall affect most the $7500 \mathrm{~km}$ of Indian coast line which has started from 2004 from the east coast. Amphibians are becoming extinct and there shall be global homogenization of flora and fauna. Mammals extinct by $21^{\text {st }}$ century in India are Mammals Asiatic cheetah: Extinct form India (Acinonyxjubatusvenaticus), Shanghai, Namdapha flying squirrel (Biswamoyopterusbiswasi), Himalayan wolf ("Canishimalayensis"), Elvira rat (Cremnomyselvira), Andaman shrew Crociduraandamanensis), Jenkins' shrew (Crocidurajenkinsi) and Nicobar shrew (Crociduranicobarica).

India's flora, Fauna, avifauna and aqua-fauna: Beautiful Indian birds, either extinct or endangered species in Anthropocene era are Great Indian Bustard (India), Red Headed Vulture, Spoon Billed Sandpiper, Jerdon's Courser, Bengal Florican, White Bellied Heron, Sociable Lapwing and many others. There is also a long list of endangered species of flora, fauna, avifauna and aqua fauna in India today.

Many tribes (Homo-sapiens) in India and also in the globe are Rabari of Gujarat, Andamanies in Andaman and Nicober islands, Nenets in Russia, Kalash in Pakistan, Batak in Philippines, Maori in New Zealand, El Molo in Kenya, Dukha in Mongolia, Goroka in Indonesia and Papua New Guinea, Piraha in Brazil and many other tribes are facing extinction.

\section{The life of the epoch "The Anthropocene" :-}

Life on our mother Earth evolved about 4 billion years BP, due to chemical action of air, water and various rocks Hazen (2006) ${ }^{[60]}$. According to reports of NASA, three PHAS and NEOS, 2016WF9, 2015BN509 and 2017BS32 are estimated to strike earth in near future which can cause mass devastation. Boffins at the US space agency, the steroid Asteroids with lower-inclination orbits are easy for reach and likely to hit earth. (http://www.dailymail.co.uk /sciencetech /article-2145699/New-Nasa-sky-scan-reveals).A 11-25m asteroid (2017 BS32) will burn up during its entry to our atmosphere and the other two shall have less impact. Very large number of PHA's and NEO's are on line for collision process with the earth system - but the epoch Anthropocene shall safely dominate for the next 1.35 million years till collision of Gliese 710 or so Bersky et al, $(2016)^{[59]}$. But the scientists have planned to bombard and explode the earth hitting PHA's and NEO's before collision and keep the earth from the apocalyptic. 
Andrew Revkin, (2011) ${ }^{[55]}$ reported that a type of unknown killer cyanobacteria oxygenated the atmosphere and extinct most of the species and can put an end to the biodiversity 2 billion years ago.

\section{Management of Anthropocene epoch:-}

Geologists and anthropologists have accepted about the fifth extinct in the globe. The sixth extinction of India and the globe is foreseen. Influences of the acceleration of climatic changes in the Anthropocene have adversely affected the underprivileged but they can have chances of survival with non-genocidal activities. The causes for main extinction are the concrete and fertilizers (adding enormous $\mathrm{P}$ and $\mathrm{N}$ to soil), sinking and shrinking of the deltas (dams and hydrologic interventions), Biomedicines (Nano-tubes and dechronification) and many others. The result of these human activities have increased the GHGs, temperature, NEOs and PHAs, meteorological extreme events etc. Some scientists have notion that the rate of extinction of species would have been much more and the modern Homosapiens would have vanished. The adverse effects of Anthropocene can be ameliorated and the extinction of species, delayed by application of modern science and technology developed.

The geo-engineering approach is to cool the climate and save the hot earth from GHG gas emissions by adding artificial aerosols in the stratosphere. To keep it safe from anthropogenic, forest fire, dust storms and drought actions are being taken by artificial heavy precipitations. The aerosol preferred to be efficient is the sulphate formation in the stratosphere Cruzen 2008. But the sulfate particles near earth surface are fatal and can make acid rain. The sulphur dioxide action cause death to a tune of 0.5 million annually, preventive actions are under consideration as per WMO report.

The carbon emission can be reduced by imposing heavy taxes on the countries who cannot maintain its carbon level in the developing countries in the world (as per The Kyoto Protocol, Canada, 2011). Ships and cargoes add a lot to the atmospheric carbon and sulphur pollutions from both coal and diesel engine.http://nce. Habitats even. Work /2014/india/.The $\mathrm{CO}_{2}$ and energy management in India needs to be done in domestic, Industrial, Transportation, and agricultural sectors. Air pollution in India can be reduced by proactive measures projected reducing mortality rate due to reduction of PM5 and PM2.5 particulates

Hydro-meteorological extreme events: In November 2013, Hiayan, a typhoon slammed and ransacked Philippines coast causing death to 10,000 people and about 9 million became homeless. Prior another VSCS, Phailine and Hudhud, generated in east Andaman sea, in $12^{\text {th }}$ Oct, 2013 and 2014 though not caused huge fatalities but devastated the Coromondol coast of India. Well preparedness and management of the cyclones were done the best and human loss was less in comparison to super cyclone at Para dip 1998 Fig 3(a).

Nano medicine: To combat human destruction and biologically process of ageing, the advances in nanotechnology, cloning and biotechnology have acted well. The Nano-medicines, with well-defined Nano-scale molecular structures, nanotubes, dendrimer-based organic devices and biologically active materials based on fullerenes can rejuvenate and slow down human ageing process. Knowledge of proteomics and genomics shall bring a revolution in medicine. Repair of damaged tissues by stem cell treatments, and biological robots created from bacteria and motile cells can deliver measured aging.

De-chronification: To continuously arrest and deplete biological ageing of human's application of intracellular respirocyte and microbivores in live cells, use of chromosome replacement therapy and repair of continuous cell damages can be done through Nano medical advances. The processes can be removal of toxins from cells, chromosome substitution therapy and cellular repair devices. It can even increase longevity from present 90 years to even 5400 years by de-chronification Freitas Jr.(1999)

From geological and hydro-metrological to biological: Mutagenic, carcinogenic or toxic microbes to reproduction shall be dominant in this epoch. The change from Holocene is not only anthropogenic but also mainly geological and hydro-metrological to biological.

The carbon pool and carbon budget: Tree cover makes major input to carbon pools on farm lands. The carbon pool adds to climatic variation mitigation and adaptation. Two third of fossil fuel is left to human which controls the carbon of the atmosphere. If from today planning, regulating the extraction, distribution and efficient use of coal, oil, electricity and atomic energy with use of maximum renewable energy not managed properly then the ambient temperature within $2^{0} \mathrm{C}$ rise cannot be maintained, then the process of ageing of the Anthropocene shall be faster. 


\section{Conclusion:-}

On stratigraphic study of recent lithology, mineralogy and limnology, the signatures of the epoch The Anthropocene during the great acceleration are found to be anthropogenic, chemo-stratigraphic, paleontological, changes in limnology and lithology, genomic and Geo-centric.

India is in the race of sixth extinction. Multi-level and polycentric efficient governance of vulnerable climatic anomalies can ameliorate and delay the effect of the great acceleration. Efficient policy makers; basin and other line managers, political leaders, economists and the teachers should stress upon effective adaptation and management which can provide better results to address the uncertainty and complexity of the epoch

Note: This paper is a prologue to the breakthrough dialogue on the Anthropocene at Cavallo point, Sausalito, California from $21^{\text {st }}$ June to $23^{\text {rd }}$ June, 2017.

Acknowledgement: I regard the inspiration and suggestions given by my beloved teachers Prof. Dr. Joy Krishna Dash during preparation of the manuscript.

\section{Reference:-}

1. Crutzen P. J., Stoermer E. F. (2000),The Anthropocene. Global Change Newsl. 41:17-18.Google Scholar

2. Crutzen P. J. (2002) Geology of mankind: the Anthropocene. Nature 415:23, (doi:10.1038/415023a).

3. Steffen, W., Crutzen, P.J., McNeill, J.R., 2007. The Anthropocene: are humans now overwhelming the great forces of Nature? Ambio 36, 614e621.

4. Steffen W., et al. (2004) Global change and the earth system:a planet under pressure (Springer, Berlin, Germany) The IGBP Book Series.

5. Syvitski, J.P.M., Vörösmarty, C.J., Kettner, A.J., and Green, P., 2005, Impact of humans on the flux of terrestrial sediment to the global coastal ocean: Science, v. 308, p. 376-380, doi: 10.1126/science.1109454. Thomas, C.D., et al., 2004, Extinction risk from climate change: Nature, v. 427, p. 145-148,

6. Crossland, C.J., ed., 2005, Coastal fluxes in the Anthropocene: Berlin, Springer, 231 p. Crutzen, P.J., 2002, Geology of mankind: Nature, v. 415, p. 23, doi: 10.1038/415023a.

7. Anderson, A.J., Mackenzie, F.T., and Lerman, A., 2005, Coastal ocean and carbonate systems in the high CO2 world of the Anthropocene: American Journal of Science, v. 305, p. 875-918,

8. IPCC report (AR 3), 2001 "Summary for Policymakers", Climate Change 2001: Synthesis Report,www.ipcc.ch/ipccreports/tar/

9. IPCC (Intergovernmental Panel on Climate Change), 2007, Climate change 2007: Synthesis report. Summary for policy makers: http://www.ipcc.ch/pdf/assessment-report/ar4/syr/ar4_syr_spm.pdf (accessed 3 Dec. 2007).

10. IPCC AR4, 2010, IPCC statement on the melting of Himalayan glaciers, Retrieved 2010-01-23.www.ipcc.ch :

11. IPCC, 2014: Climate Change 2014: Mitigation of Climate Change. Contribution of Working Group III to the Fifth Assessment Report of the Intergovernmental Panel on Climate Change [Edenhofer, O., R. Pichs-Madruga, Y. Sokona, E. Farahani, S. Kadner, K. Seyboth, A. Adler, I. Baum, S. Brunner, P. Eickemeier, B. Kriemann, J. Savolainen, S. Schlömer, C. von Stechow, T. Zwickel and J.C. Minx (eds.)]. Cambridge University Press, Cambridge, United Kingdom and New York, NY, USA.

12. Sir David Attenborough, 2006, The Truth About Climate Change, October 22, 2006

13. Stormberg Joseph, 2013, What Is the Anthropocene and Are We in It?,http://www.smithsonianmag. com/science- nature/what-is-the-anthropocene-and-are-we-in-it-164801414/

14. Tondon S. K., Chkravorti P. P., Singh V, 2014, Geological and tectonic frame work of India: providing context to geomorphologic development, Springer, land scape and landforms of India, pp-1-3

15. Peter Fisher, 2014, The 'pre-Holocene' climate is returning - and it won't be fun, Adjunct Professor, Global, Urban and Social Studies, RMIT Univ., Victoria state, http: //theconversation.com/the-pre-holocene-climate-isreturning-and-it-wont-be-fun-27742

16. Bruce Hull, 2015, India as Anthropocene, Virginia Tech or the Center for Leadership in Global Sustainability, Virginia Polytechnic Inst. and State Univ. - College of Natural Resources and Environment

17. Matt Atherton, 2016, Climate change: Middle East and North Africa to become uninhabitable forcing mass migration, http://www.ibtimes.co.uk/climate-change-middle-east-north-africa-become-uninhabitable-forcingmass-migration-1558023

18. Hannah Osborne, (2015), Anthropocene era: Man's Dominion over the Earth began in 1610, http://www .ibtimes.co.uk/anthropocene-era-mans-dominion-over-earth-began-1610-1491460 
19. Stanley C. Finney, Lucy E. Edwards,2016, The "Anthropocene" epoch: Scientific decision or political statement?, Volume 26 Issue 3-4 (March-April 2016) GSA TODAY

20. Zalasiewicz, J., Williams, M., Smith, A., Barry, T.L., Coe, A.L., Bown, P.R., Brenchley, P.,Cantrill, D., Gale, A., Gibbard, P., Gregory, F.J., Hounslow, M., Kerr, A.C., Pearson, P., Knox, R., Powell, J., Waters, C., Marshall, J., Oates, M., Rawson, P., Stone, P., 2008. Are we now living in the Anthropocene? Geological Society of America Today 18, $4 \mathrm{e} 8$.

21. Zalasiewicz J., Williams M., Steffen W., Crutzen P. (2010) The new world of the Anthropocene. Environ. Sci. Technol. 44:2228-2231, (doi:10.1021/es903118j).

22. Zalasiewicz, J., Cita, M.B., Hilgen, F., Pratt, B.R., Strasser, A., Thierry, J., Weissert, H.,2013. Chronostratigraphy and geochronology: a proposed realignment. GSA Today 23 (3),

23. (a)Zalasiewicz, J., Williams, M., Waters, C.N., 2014a. Can an Anthropocene series be defined and recognized? In: Waters, C.N., Zalasiewicz, J., Williams, M., and (b)Zalasiewicz, J., Williams, M., Waters, C.N., Barnosky, A.D., Haff, P., 2014b. The techno fossil record of humans. Anthropocene Review 1, 34e43. http:// dx.doi.org/10.1177/2053019613514953.

24. Barnosky, A.D., 2008. Mega fauna biomass tradeoff as a driver of quaternary and future extinctions. Proceedings of the National Academy of Sciences Unites States of America 105 (Suppl. 1), 11543e11548.

25. Ellis, E.C., 2011. Anthropogenic transformation of the terrestrial biosphere. Philosophical Transactions of the Royal Society A369, 1010e1035.

26. Ellis, E.C., Antill, E.C., Kreft, H., 2012. All is not loss: plant biodiversity in the Anthropocene. PLoS ONE 7, e30535. http://dx.doi.org/10.1371/ journal.pone.0030535.

27. Ellis, E.C., Kaplan, J.O., Fuller, D.Q., Vavrus, S., Klein Goldewijk, K., Verburg, P.H., 2013. Used planet: a global history. Proceedings of the National Academy of Sciences110 (20), 7978e7985.

28. Ellis, M.A., Snelling, A. (Eds.), 2014, .A Strati graphical Basis for the Anthropocene, Geological Society, London, Special Publications 395, pp. 39e53. http://dx.doi.org/10.1144/ SP395.16.

29. Wilkinson, I.P., Poirier, C., Head, M.J., Sayer, C.D., Tibby, J., 2014. Micropalaeontological signatures of the Anthropocene. In: Waters, C.N., Zalasiewicz, J., Williams, M., Ellis, M.A., Snelling, A. (Eds.), A Strati graphical Basis for the Anthropocene, Geological Society, London, Special Publications 395, pp. 185e219. http://dx.doi.org/10.1144/SP395.14.

30. Foley, S.F., Gronenborn, D., Andreae, M.O., Kadereit, J.W., Esper, J., Scholz, D., Poschl, U., Jacob, D.E., Sch $€$ one, B..R., Schreg, R., V $€$ ott, A., Jordan, D., Lelieveld, J., $€$ Weller, C.G., Alt, K.W., GaudzinskiWindheuser, S., Bruhn, K.C., Tost, H., Sirocko, F., Crutzen, P.J., 2013. The Palaeo-anthropocene. The beginnings of anthropogenic environmental change. Anthropocene 3, 83e88.

31. Rebecca Morelle, (2015), Anthropocene: New dates proposed for the 'Age of Man', Science and Environment,

32. Waters, C.N., Zalasiewicz, J., Williams, M., Ellis, M.A., Snelling, A. (Eds.), 2014a.A Strati graphical Basis for the Anthropocene. Geological Society, London, Special Publications 395. Waters, C.N., Zalasiewicz, J., Williams, M., Ellis, M.A., Snelling, A., 2014 b.

33. Steffen, W., Sanderson, A., Tyson, P.D., Jaeger, J., Matson, P.A., Moore, B., III, Oldfield, F., Richardson, K., Schnellnhuber, H.J., Turner, B.L., and Wasson, R.J., 2004, Global Change and the Earth System: A Planet under Pressure: Berlin, SpringerVerlag, 336 p.

34. Barnosky, A.D., 2014. Paleontological evidence for defining the Anthropocene. In: Waters, C.N., Zalasiewicz, J., Williams, M., Ellis, M.A., Snelling, A. (Eds.),2013, A Strati graphical Basis for the Anthropocene, Geological Society, London, Special Publications 395, pp. 149e165. http://dx.doi.org/10.1144/SP395.6.

35. Wolff, E.W., 2014. Ice sheets and the Anthropocene. In: Waters, C.N., Zalasiewicz, J., Williams, M., Ellis, M.A., Snelling, A. (Eds.), 2013, A Strati graphical Basis for the Anthropocene, Geological Society, London, Special Publications 395, pp. 255e263. http://dx.doi.org/10.1144/SP395.10.

36. Walker, M.J.C., Berkelhammer, M., Bjorck, S., Cwynar, L.C., Fisher, D.A., Long, A.J., € Lowe, J.J., Newnham, R.M., Rasmussen, S.O., Weiss, H., 2012. Formal subdivision of the Holocene Series/Epoch: a discussion paper by a Working Group of INTIMATE (Integration of ice-core, marine and terrestrial records) and the Sub commission on Quaternary Stratigraphy (International Commission on Stratigraphy). Journal of Quaternary Science 27, 649e659. http://dx.doi.org/10.1002/jqs.2565.

37. Hancock, G.J., Tims, S.G., Fifield, L.K., Webster, I.T., 2014. The release and persistence of radioactive anthropogenic nuclides. In: Waters, C.N., Zalasiewicz, J.

38. Wolff, E.W., 2014. Ice sheets and the Anthropocene. In: Waters, C.N., Zalasiewicz, J., Williams, M., Ellis, M.A., Snelling, A. (Eds.), A Strati graphical Basis for the Anthropocene, Geological Society, London, Special Publications 395, pp. 255e263. http://dx.doi.org/10.1144/SP395.10. First Published Online November 25, 2013. 
39. Waters, C.N., Syvitski, J.P.M., Gałuszka, A., Hancock, G.J., Zalasiewicz, J., Cearreta, A., Grinevald, J., Jeandel, C., McNeill, J.R., Summerhayes, C., 2015. Can environmental radiogenic signatures define the beginning of the Anthropocene Epoch? Bulletin of Atomic Scientists (submitted for publication).

40. Morrison Kathleen D., 2015, Provincializing the Anthropocene, http://www.india-seminar. com/2015/673/673_kathleen_morrison.htm

41. Jain V., Sinha R., Singh L.P. and Tandon S. K., 2016, River systems in India, Proc Indian National Science Academy, 82(3), pp-747-761

42. Jacob Schewe and Anders Levermann, 2012 Environ. Res. Lett. 70440235 November 2012, A statistically predictive model for future monsoon failure in India.

43. Levermann A, Schewe J, Petoukhov V, Held H (2009) Basic mechanism for abrupt monsoon transitions. ProcNatlAcadSci USA, 10.1073/PNAS.0901414106.

44. Koronowski Ryan, 2016, Record-Breaking Hot Ocean Temperatures Are Frying The Great Barrier Reef, https://thinkprogress.org/record-breaking-hot-ocean-temperatures-are-frying-the-great-barrier-reef-

45. Dana Nuccitelli (2016), O’Day, 2016, The atmosphere is being radicalized' by climate change, https://www.theguardian.com/environment/climate-consensus

46. Cawley Gavin C., 2011, On the Atmospheric Residence Time of Anthropogenically Sourced Carbon Dioxide, School of Computing Sciences, University of East Anglia, Norwich, U.K.

47. LehyStephen, 2007, Heading for +2 degrees C (3.6 degrees F) Carbon Use Must Peak by 2015 Scientists Warn,https://stephenleahy.net/tag/greenhouse-gas/page/6/

48. Unnikrishnan A. S., Rupa Kumar K., Fernandes S. E., Michael G. S. and Patwardhan S. K., (2006), Sea level changes along the Indian coast: Observations and projections, Current Sc., Vol 90(3), pp. 362 -368

49. Shetye S. R., Gouveia and PathaK M. C., 1990, Vulnerability of the Indian coastal region to damage from sea level rise, Current Science, Vol 59(3), 1990, pp. 152-156

50. Mishra S.P. and Jena J. G. (2014) "Migration of Tidal Inlets of Chilika Lagoon, Odisha, India -A Critical Study" Int. Journal of Engineering and Technology, Vol 6 No, 2014, pp. 2453-2464

51. IPCC, 2014: Climate Change 2014: Synthesis Report. Contribution of Working Groups I, II and III to the Fifth Assessment Report of the Intergovernmental Panel on Climate Change [Core Writing Team, R.K. Pachauri and L.A. Meyer (eds.)]. IPCC, Geneva, Switzerland, $151 \mathrm{pp}$.

52. Ventor Craige J., 2010, 'Minimal' cell raises stakes in race to harness synthetic life, Nature 531, 557-558 (31 March 2016) doi:10.1038/531557a

53. Vaughan Adam R., James D. Lee, Misztal Pawel K, Stefan Metzger, de Shaw Marvin D., Alastair C. Lewis, et al, (2016), Spatially resolved flux measurements of Knox from London suggest significantly higher emissions than predicted by inventories, https://www.theguardian.com/environment/2016/ jan/07/humanimpact-has-pushed-earth-into-the-anthropocene-scientists

54. Singh P. K. \& Dhiman R. C., 2012, Climate change and human health: Indian context, Review article, J Vector Borne Dis 49, June 2012, pp. 55-60

55. Revkin Andrew C., 2011, Confronting the 'Anthropocene', New york times, 11th May, 2011 ,http://www. smithsonianmag.com/science-nature/what-is-the-anthropocene-and-are-we-in-it-

56. Syvitski et al, Sinking deltas due to human activities, Nature Geoscience, 2009

57. Gupta H, Shuh-Ji Kao, Minhan Dai', 2012, The role of mega dams in reducing sediment fluxes: A case study of large Asian rivers, Journal of Hydrology, 2012

58. Mishra S. P., 2016, Modeling of Flow/Sediment Input at Delta Head Rivers in Odisha India, International Jour. of Multidisciplinary Engineering in Current Research, Volume 1, Issue 1, September 2016, http://ijmec.com/

59. Berski F P and Dybczyński P, A., (2016), Gliese 710 will pass the Sun even closer, Close approach parameters recalculated based on the first Gaia data release, Int. jour. of Astronomy and Astrophysics, Vol L-10, Page 1-4

60. Hazen R.M., 2006, Genesis: The Scientific Quest for Life's Origins', Washington (DC): Joseph Henry Press, 368 pages.

61. Davos-Klosters, 2017, India and the new epoch Livemint, | E-Paper (2004), http://www.livemint.com /Opinion/Tgq73SZ0VH7zc1cX36cfDI/ 